\title{
Çalışma Hayatında Cinsiyet Ayrımcılığı ve Türk İş Hukukunda Kadınları Korumaya Yönelik Düzenlemeler
}

\author{
Ahmet TERZİOĞLU1 \\ ORCID: 0000-0002-1916-0421
}

Fatmanur AKSÖZ ${ }^{2}$

ORCID: 0000-0003-4765-0986

DOI: $10.54752 /$ ct.1060809

Öz: Kadınlar yüzyıllar boyunca çalısma hayatında var olabilmek adına çeşitli mücadeleler vermiştir. Günümüz koşulları değerlendirildiğinde toplumsal yapinın değişmeye başlaması ve ülke ekonomisinin sürdürülebilir kalkınması adına kadın işgücünün ne kadar önemli olduğu gerçeği açıkça ortadadır. Ancak bu gerçekliğe rağmen günümüzde çalışma hayatında kadınlar cinsiyet ayrımcilığ başta olmak üzere çeşitli sorunlarla karşılaşmaya devam etmektedir. Bu doğrultuda hem kamusal alanda yüzyıllardır süregelen eril hâkimiyet ve bunun getirdiği toplumsal ön yargılar, hem kadınların fiziksel açıdan erkeklere nazaran daha güçsüz olması hem de ağırlıklı olarak aile içi sorumlulukların kadınlarda olması, kadınlara özgü koruyucu yasal düzenlemeleri gerekli kılmaktadır. Bu noktadan hareketle çalışma kapsamında 4857 sayılı İş Kanunu'nun kadınları korumaya yönelik öngördüğü düzenlemeler incelemeye tabi tutulmuştur. İş Kanunu kapsamındaki bu düzenlemeler çalışan kadınları korumaya yönelik açıkça hükümler öngörse de bu hükümlerin hayata geçirilmesi gerektiği ve bunun için de toplumdaki her bir bireyden yönetişim ağ1 içerisindeki her bir kuruluşa önemli görevler düşmektedir.

Anahtar kelimeler: Çalişan kadın, İş Kanunu, Sorunlar, Cinsiyet Ayrımclly̆g

Gender Discrimination in Working Life and Regulations to Protect Women in Turkish Labor Law

Abstract: Women have struggled for centuries in order to exist in working life. When today's conditions are evaluated, it is obvious how important the female workforce is for the social structure to begin to change and for the sustainable development of the country's economy. However, despite this reality, women continue to face

${ }^{1}$ Dr. Öğr. Üyesi, Harran Üniversitesi İ.İ.B.F. Kamu Yönetimi Bölümü,

2 Arş. Gör. Harran Üniversitesi İ.İ.B.F. Kamu Yönetimi Bölümü, Makale Geliş Tarihi: 14.07.2021 - Makale Kabul Tarihi: 10.12.2021 
various problems in working life, especially gender discrimination. In this direction, both the masculine dominance in the public sphere for centuries and the social prejudices brought by it, both the fact that women are physically weaker than men and that women have predominantly domestic responsibilities, necessitate protective legal regulations specific to women. From this point of view, within the scope of the study, the regulations stipulated by the Labor Law No. 4857 to protect women were examined. Although these regulations within the scope of the Labor Law clearly envisage provisions to protect working women, these provisions must be implemented, and within this, every individual in the society and every organization within the governance network have important duties.

Keywords: Working women, Labor Law, Problems, Gender Discrimination

\section{Giriş}

Cinsiyet ayrımcılluğ kadınların gerek sosyal hayatta gerekse iş hayatında karşılaştıkları sorunların başında gelmektedir. Söz konusu ayrımcılık, kadınların erkekler ile eşit firsatlara sahip olamamasına yol açmakta bu durum ise kadınların tüm hayatını şekillendirmektedir. Oysaki kadınların çalışma hayatında erkekler ile eşit koşullara sahip olması hayati önem taşımaktadır. Çünkü kadınlar toplumun neredeyse yarısını oluşturan bir kesim olarak çalışma hayatı için ciddi bir potansiyel arz etmektedir. Dolayısıyla kadınların çalışma hayatında aktifleşmeleri yalnızca kendilerine değil topluma ve ülke kalkınmasına da önemli katkılar sunacaktır.

Kadınların çalışma hayatında erkeklere nazaran dezavantajlı konumda oldukları gerek yazında gerek günlük yaşamda kabul edilen bir gerçekliktir. Bunun arka planında ise kadınların annelik ve eşlik rolleri gereği ev içi sorumluluklarının daha fazla olması yer almaktadır. Söz konusu olan bu dezavantajlı konum kadın çalışanları korumaya yönelik düzenlemeleri gerekli kılmıştır. Kadınların iş yerinde maruz kaldıkları cinsiyet ayrımcılı̆̆ başta olmak üzere çeşitli sorunlar yasal düzenlemelere konu olmuştur. Bu bağlamda çalışma kapsamında 4857 sayllı İş Kanunu'nun kadın çalışanları korumaya yönelik düzenlemeleri ele alınacaktır.

Çalısmada öncelikli olarak çalışma hayatında cinsiyet ayrımcılı̆̆ının kuramsal ve tarihsel gelişiminin sağlam bir zemine oturtulması adına kadınların tarihsel süreç içerisinde çalışma hayatına katılımlarına, çalışma hayatında yer almalarının önemine, kadınların çalışma hayatındaki konumlarında toplumsal cinsiyetin etkisine ve çalışma hayatında karşılaştıkları sorunlara ayıı ayrı değinilecektir. Ardından çalışan kadınları korumaya yönelik Anayasal düzenlemeler incelendikten sonra İş Kanunu'nda yer alan eşitlik ilkesi ve ayrımcılık yasağı, kadın işçileri çalıştırma yasağı, hamilelik ve analık halinde kadın işçilerin sahip olduğu haklar, kadınları tacize karşı koruyan düzenlemeler ve kadın işçilerin kıdem tazminatı bakımından hakları incelenerek değerlendirmeye tabi tutulacaktır. 


\section{Çalışma ve İş Kavramı}

Çalışma, hayatımızın her alanında var olan oldukça geniş bir kavramdır. Bu kavrama dair farklı algılamalar ve tanımlamalar söz konusudur. Eski Yunanlılar ve Romalılar'da çalışma "acı, yorgunluk, zahmet" anlamları ile ifade bulmuştur. Çalışma kavramı, zihinsel ve fiziksel bir gayret ile birlikte ortaya yeni bir şey çıaran bir emek sürecini ifade etmektedir. Dolayısıyla çalışma, herhangi bir amaç doğrultusunda ortaya konan çabadır (Ören ve Yüksel, 2012: 37).

Çalışma kavramı ile iş kavramı yaygın bir biçimde aynı anlamda kullanılmaktadır. Oysaki iş, endüstrileşme ile birlikte ortaya çıkan bir kavramdır. İş kavramının çalışma ile bağlantılı bir kavram olduğu esastır ancak ayrım noktası ücrettir. Dolayısıyla iş, ücret karşılığı yapılan çalışmadır. Kısaca, çalışma "belirli bir üretimi amaçlayan fiæi iksel ve zibinsel insan faaliyetlerinin toplamı" şeklinde ifade edilirken, bu faaliyet için çalışanın ortaya koyduğu emeğe paralel olarak takdim edilen bir ödeme olduğunda iş kavramından söz edilmektedir. Böylece iş kavramının Sanayi Devrimi ile birlikte ortaya çıktığı ve bireylerin modern çalışma biçimlerini ifade ettiği söylenebilir. Sanayi Devrimi öncesinde bireyler kendisi ve ailesi için üretim yaparken, sanayileşme ile birlikte belirli bir ücret karşıllı̆ında, belirli bir işveren karşı, işverenin çalışma kurulları kapsamında emeğini ortaya koymaya başlamış ve yapılan çalışma işe evrilmiştir. Tabi ki bu durum yeni ekonomik, sosyal, kültürel ve psikolojik dönüşümleri de beraberinde getirerek bu dönüşüm içerisinde olgunlaşmıştır (Işık, 2013: 105).

Mevzuatımızda iş kavramının genel bir tanımı bulunmamaktadır. Ancak iş kavramının tanımına dair ortak payda da ekonomik bir değer taşıyan faaliyet olduğunu söylemek gerekmektedir. Bu noktada en basit hali ile başka bir kişi adına yerine getirilen ve ona yarar sağlayarak ihtiyacını gideren ekonomik bir değer taşıyan faaliyetler iş kavramına dâhildir (Narmanlıŏ̆lu, 2014: 75).

\section{Çalışma Hayatında Kadın-Erkek Eşitsizliği ve Cinsiyet Ayrımcılığı}

Geçmişten günümüze kadınlar toplumun her alanında cinsiyete dayalı ayrımcilıkla karşılaşmaktadır. Bu durumun arka planında ise toplumsal cinsiyet rolleri gereği yüzyıllardır kadının özel alanla erkeklerin ise kamusal alanla özdeşleştirilmesi yer almaktadır. Kamusal alanın hâkim aktörleri erkekler, sosyal, ekonomik ve siyasal hayatta söz sahibi olurken kadınlar daha dezavantajlı ve ikincil bir konumda kalmıştır (Derdiyok, 2014: 2). Bu doğrultuda süregelen erkek egemenli yap1 ile birlikte günümüzde kadınların cinsiyet ayrımcllı̆ı yaşadığı temel alanlardan biri de çalışma hayatıdır. Bu noktadan hareketle bu başlık altında kadınların tarihsel süreç içerisinde çalışma hayatına katılımları, istihdamlarının önemi, cinsiyet ayrımcılığı ve toplumsal cinsiyet, kadınların çalışma hayatında karşılaştıkları sorunlar ele alınmıştır. 


\section{Tarihsel Süreç İçerisinde Kadınların Çalışma Hayatına Katılımları}

Dünya üzerinde kadınların çalışma hayatında yer almaları oldukça uzun bir süreci gerektirmiştir. Tarihin eski zamanlarından günümüze dek, kadının yeri evi olarak temel görevi de ailesine, çocuklarına ve eşine bakmak olarak görülmüştür. Toplum nezdindeki bu düşünce toplumsal alanda erkek egemenliğini hâkim kılmıştır. Tarım ile beraber yerleşik yaşama geçilmesi kadınların toplumdaki ikincil statüsünü değiştirememiştir (Korkmaz vd, 2013: 18). I ve II. Dünya Savaşları'nda erkeklerin silah altına alınmasıyla beraber iş gücü ihtiyacını karşılamak adına çalışma hayatında kadınlara yer verilmeye başlanmıştır. Sanayileşme ile ise kadının aile ve çalışma hayatındaki pozisyonunda dönüşümler meydana gelmiştir. Kadınların emeklerinin karşılığında ücret alması ise ilk kez Sanayi Devrimi ile başlamışır (Kocacık ve Gökkaya, 2005: 196).

Ancak tarım toplumlarında iş gücüne katılım yüksek iken sanayileşme ve kentleşmeye bağlı olarak işgücüne katılım önce azalan daha sonra ise eğitim seviyesindeki artışa paralel olarak artış göstermektedir. Bu durum kadınların tarımda ücretsiz aile işçisi olarak çalışıp üretime dahil olmasına rağmen, kente göç edilmesinden sonra kadınların eğitim seviyesinin düşüklüğü ve sanayi iş gücü niteliği taşımaması gibi sebeplerden kaynaklanmaktadır (Karabıyık, 2012: 233).

1950’li ylllar ile birlikte gelişmiş ülke ekonomilerinde sektörel bir dönüşüm yaşanmış ve tarımda, sanayide çalışan kadınlar artık hastane, kamu kurumları gibi hizmet sektöründe çalışmaya başlamıştır. 1970'lere gelindiğinde ise ticaretin serbestleşmesi ve çok uluslu şirketlerin sayıca artması ucuz emeği ortaya çıkarmışırı. $\mathrm{Bu}$ durumdan ise ağırlıklı olarak etkilenen kesim kadınlar olmuştur. Böylece kadınların düşük ücretlerde çalışması zorunlu kılınmıştır. Yine de bu yıllarda kadınların kötü şartlarda da olsa ekonomik yaşamda faal olmaları, kadınların çalışma haklarına dair düzenlemelerin yapılmasına ön ayak olmuştur (Korkmaz vd, 2013: 1850).

Netice itibariyle kadınlar insanlık tarihi boyunca farklı statülerde ve koşullarda ekonomik faaliyetlere katılmışlardır. Bu süreçte sanayi devrimi kadınlar için bir kırılma noktasını oluşturmaktadır. Nitekim Sanayi Devrimi ile birlikte gelişen teknoloji, dönüşen sosyal ve ekonomik ilişkiler, kadınların artık ücret karşıllğında ekonomik faaliyetlerde yer almasına firsat tanımış ve "ücretli kadin is güıй” kavramı gün yüzüne çıkmışır. Ücret kadın yaşamında kritik bir öneme sahiptir. Öyle ki ücret kadının, toplum içerisinde görünürlüğünün ve söz hakkının artmasını sağlamaktadır. Ayrıca hayatın her alanında kadının eşitlik mücadelesine katkısı yadsınamaz ölçüdedir. En önemlisi ücret, kadının hem kendisi hem de toplum tarafindan bir birey olarak kabul edilmesinde etkin bir araçtır. Dahası ücret, sanayi devrimi öncesi ücret almaksızın çalışan kadınların işgücüne dâhil edilmemesi sorununa önemli bir çözüm getirmektedir. Böylece ekonomik faaliyete katılmayan ve katılan kadın ayrımı ücret sayesinde belirginleşmiştir (Parlaktuna, 2010: 1217). 
Ülkemizde ise kadınların aktif olarak işgücüne katılımları 1950'lerin sonuna dayanmaktadır. Bu durum ülke ekonomisinin 1950’lere dek tarımsal üretime dayanması, ekonomik yapıda ortaya çıkan değişiklikler ve bunun beraberinde getirdiği sosyo-kültürel dönüşümlerden kaynaklanmaktadır. Ülkemizde kadınların iş gücüne katılımları kentlerde kırsal bölgelere nazaran daha düşüktür. Bunun sebebi, kentlerde " $e v$ kadmı" sıfatı altında iş gücüne dahil edilmeyen kadınların kırsal bölgelerde "ürretsiz aile iş̧isi" olarak iş gücüne dahil edilmeleridir. Ayrıca bu durumda kentlerdeki kadınların eğitim seviyelerinin düşüklügü nedeniyle istihdam edilmemeleri de etkili olmaktadır (Karabıyık, 2012: 235-236).

Türkiye'de kadın istihdamı ile Avrupa Birliği ülkelerindeki kadın istihdamı kıyaslandığında Türkiye'nin daha geride olduğu görülmektedir. Ayrıca çalışmayan veya âtıl şeklinde karakterize edilebilecek kadın oranı da oldukça düşük oranlardadır. $\mathrm{Bu}$ düşük oranlar kadınların çalışmalarına dair mevcut kültürel etkenler, ekonomik yapının zayıf istihdama elverişli kapasitesi, kırdan kente göç gibi bazı nedenler ile açıklanabilir (Dedeoğlu, 2009: 42).

Türkiye'nin, Avrupa Birliği’ne uyum sürecinde çeşitli cinsiyet eşitliği politikaları İş Kanunu ve diğer yasal düzenlemeler ekseninde ulusal mevzuata dâhil edilmiştir. Fakat günümüzde bir paket anlayışı kapsamında uygulamaya konulan eşit davranma, eşit ücret, gece çalıştırma, doğum izni, çocuk bakımı, ebeveyn izni, esnek çalışma gibi yasa değişiklikleri yalnızca kadınların bir kısmının iş yaşamında olumlu etkiler sağlamıştır. Nitekim bu düzenlemelerin uygulamaya aktarılmasında çoğunlukla sıkıntılar yaşanmasının yanı sıra bazı durumlarda kadınları anne ve eş rollerine teşvik ederek çalışma hayatı açısından caydırıcı da olabilmektedir. İş yerlerinde kreş ve bakım odalarına dair düzenlemeler ise yetersiz kalabilmekte ve bu durum devletin kamusal çocuk bakım hizmetlerini daha fazla geliştirmesini, yaygınlaştırmasını gerektirmektedir. Kreş ve bakım odalarına dair düzenlemeler tekrar tertip edilmeli, sayısı ve vasfi arttırılmalı, maliyetleri azaltılmalıdır (Dedeoğlu, 2009: 53). Söz konusu olan bu düzenlemeler çalışmanın ilerleyen bölümlerinde irdelenecektir.

\section{Kadınların Çalışma Hayatındaki Önemi}

Ülkemizde kadınların çalışma hayatına katılımının önemi her ne kadar Kalkınma Plan ve Programları ve bir dizi politika dokümanlarında siklikla vurgulansa da henüz istenilen seviyeye erişilememiştir (Karabıyık, 2012: 235).

Kadınlar, toplum zihnine yerleşmiş nesilden nesle aktarılan geleneksel kalıpların yıkılması, her iki cinse de eşit fırsatların tanınması, kadınların çalışma hayatlarında önüne çıkan engellerin ve dezavantajlı konumlarının aşılmasına yönelik tedbirlerin alınması ile toplumsal alanda haklarına erişebilecek, saygı ve değer görebilecek, kendi hayatlarının kontrolünü kendileri sağlayabilecek ve söz sahibi bir birey olabilecektir. Bu bakımdan kadınların çalışma hayatında yer alması oldukça önem arz etmektedir. Ek olarak eğitim, çalışma hayatına katılım ve siyasal katılım ilişkisine de değinmek gerekmektedir. Zira kadınların eğitim seviyesi çalışma 
hayatına katılımlarında iyileştirici etki gösterecek bu durum ise siyasal katılımları ile paralel bir seyir izleyecektir (Pekel, 2019: 37).

Kadınlar, toplumda ön planda bulunmayan ancak toplumsal ilerleme için fevkalade önemli etkileri bulunan ciddi bir toplumsal kesimi oluşturmaktadır. Öyle ki toplum, kadının üretkenliği ve etkinliği ölçüsünde gelişebilmektedir. Dolayısıyla kadınların çalışma hayatında yer alması, insanın ve insan emeğinin özgürleşmesinde, toplumsal ve ekonomik sürdürülebilir kalkınma sürecinde büyük önem arz etmektedir. Aynı zamanda kadının çalışması hanenin gelir düzeyini artıracaktır. Türkiye gibi geleneksel toplumsal yargılardan dolayı erkeğin eve gelir sağlamakla yükümlü olduğu tek kazançlı aile modeli, ekonomik krizlerden, erkeğin işsiz kalmasından veya hastalık, iş kazası gibi iş göremezlik durumlarından derinden etkilenmektedir. $\mathrm{Bu}$ doğrultuda yoksullukla mücadele açısından kadınların da çalıştığı çift kazançlı hane modelinin önemli olduğu düşünülmektedir. Öte yandan bu durum kadının öncelikle ailede daha sonra ise toplumdaki statüsünü yükseltecek böylece ev ve toplum içerisinde daha çok söz sahibi olacaktır. Bu durum toplum içerisinde erkek lehine olan güç dengelerinin değissmesine ve daha eşit bir toplumsal yap1 oluşmasına katk1 sunacaktır. Dahası toplumun çekirdeğini oluşturan aile yapıları güçlenecek bu durum da toplumun güçlenmesine ve daha özgürlükçü ve eşitler arası ilişsilere dayanan demokratik birlikteliklere kucak açacaktır (Karabıyık, 2012: 240). Aile gelirinin artmasına, ailedeki etkinliğinin artmasına bağlı olarak kadınlarım yaşam standartları yükselecektir. Kadınların aile içerisinde şiddet, ekonomik baskı gibi maruz kaldıkları pek çok sorunla mücadele etmeleri kolaylaşacaktır (Korkmaz vd, 2013: 1849). Bu durum sayesinde ise aile birliklerinin maddiyata ve korkuya değil anlayış ve sevgiye dayalı daha sağlıklı bir yapıya kavuşacağ1 ümit edilmektedir. Ayrıca önemle belirtmek gerekir ki aile ve toplum içerisinde güçlenen ve daha etkin olan kadınlar daha güçlü nesiller yetiştirecektir. $\mathrm{Bu}$ nedenle yalnızca bugün için değil gelecek için de kadınların çalışma hayatında yer almalarının hayati önem taşıdığı kanaatine hâsıl olunmuştur.

Çalışma hayatı kadınlara yalnızca ekonomik özgürlük kazanmalarını sağlamaz aynı zamanda toplumdaki saygınlıklarını, özgüvenlerini ve aile içerisindeki statülerini geliştirir (Korkmaz ve Korkut, 2012: 45). Öte yandan önemle belirtmek gerekir ki kadınların ücret karşılığında çalışma hayatına katılması yalnızca kendilerine fayda sağlamamaktadır. Aynı zamanda ülkelerin dengeli ve sürdürülebilir kalkınması açısından kadın istihdamı kilit bir role sahiptir. Çünkü hem ülke hem de dünya nüfusunun neredeyse yarısını oluşturan kadınlar toplumun azımsanamayacak bir kesimini oluşturmaktadır. Bu nedenle kadın işgücünün nicel ve nitel açıdan gelişimi iktisadi büyümenin temel kaynaklarındandır. Kadın istihdamının, ülkeye sunulacak ekonomik katkının yanı sıra toplumsal yapıyı da güçlendirici etkisi bulunmaktadır. Bu doğrultuda kadının aile ve toplumsal yapıda statüsünün artması daha güçlü bir aile ve toplumsal yapıya zemin oluşturacaktır. Bu olumlu etkiler ülkedeki sosyal ve kültürel gelişime de pozitif olarak yansıyacak ve katk1 sunacaktır (Parlaktuna, 2010: 1217). 


\section{Cinsiyet Ayrımcılığı ve Toplumsal Cinsiyet Ekseninde Çalışma Hayatında Kadının Konumlanması}

Cinsiyet ayrımcllı̆̆ı, bir kadına sırf cinsiyetinden ötürü, bir erkeğe davranıldığından daha olumsuz davranılması (dolaysız ayrımcılık) veya biçimsel olarak başlangıçta eşitlikçi görünen bir yaklaşımın sonradan kadın açısından ayrımcı etkiler doğurması (dolaylı ayrımcilık) olarak tanımlanabilir (İleri, 2016: 139). Cinsiyet ayrımcıllğı, kişilerin niteliklerine ve yeteneklerine bakılmaksızın sırf kadın olmalarından dolayı erkeklerden farklı muamele görmelerini ifade etmektedir. Doğal olarak cinsiyet ayrımcılığ1 pek çok alanda kadınların varlık gösterememesine, erkeklerle eşit imkânlara sahip olamamasına, eşit koşullarda hayatını idame ettirememesine yol açmakta ve sosyal davranışlarını şekillendirmektedir. Çalışma kapsamında göz önünde bulundurduğumuz mesleki cinsiyet ayrımcılığı çerçevesinde de kadınlar yüzyllar boyunca eğitime ve istihdama erişimleri erkeklere nazaran çok daha kisttlı olmuştur. Bu kapsamda iş performans1, nitelikleri ve yeteneklerinden ziyade sırf kadın olmaktan dolayı maruz kalınan cinsiyet ayrımcllı̆ı açık ve örtülü biçimlerde gerçekleşebilmektedir. Örnek vermek gerekirse iş ilanında sadece erkeklerin başvurularının kabul edilmesi, yapılan aynı işten erkeklerin daha çok ücret kazanması, hamilelik gerekçesi ile kadının işten çıkarılması açık cinsiyet ayrımcilığı iken (Alparslan vd, 2015: 68) işe alımlarda küçük çocuğu olan kadınların tercih edilmemesi, kadınların daha çok yarı zamanlı işlerde çalıştırılmaları ve işten ilk yarı zamanlı işçilerin çıkarılması, benzer şekilde teşvik primlerinde tam zamanlı işçilerin tercih edilmesi ve çoğunlukla yarı zamanlı olarak çalışan kadınların bu durumdan yararlanamaması gibi durumlarda ise örtülü ayrımcılık söz konusudur (Alparslan vd, 2015: 69).

Ataerkil toplum yapısında erkek üstün ve imtiyazlı bir konuma sahip iken kadinlar "zayzf cinsiyet" olarak kabul edilmektedir. Toplum nezdindeki bu genel kabul ekseninde kadınların toplumsal rollerinin belirlenmesini biyolojik farkllıklar üzerinden açıklamak oldukça sı̆̆ bir bakış açısıdır. Zira kadın ve erkeğe biçilen roller biyolojik özelliklerinden ziyade toplumsal evrimin bir neticesidir (İleri, 2016: 138).

Nitekim cinsiyet kavramı ise kadın ve erkeklere özgü biyolojik ve fizyolojik özellikler üzerinden tanımlanırken toplumsal cinsiyet bunun çok daha ötesinde anlam içeren bir kavramdır. Toplumsal cinsiyet en basit haliyle kadın ve erkeğe toplum tarafindan atfedilen rol ve sorumlulukları ifade etmektedir (Alparslan vd, 2015: 68).

Toplumsal cinsiyet dünyanın hemen hemen her yerinde kendini farklı ölçülerde de olsa gösteren bir eşitsizlik sorunudur. Toplumsal cinsiyete dayalı kadına ve erkeğe atfedilen davranış kalıpları, roller, sorumluluklar ve değerler erkeği üstte ve önde tutan ayrıştırıcı bir özellik taşımaktadır. Kadın, toplumsal cinsiyeti suretiyle erkekten ayrı ve öteki olarak benimsenmektedir. Kadınlık, erkeklik statülerinin tanıdığı imkân doğrultusunda eril hâkimiyetin olduğu kültür tarafindan oluşturulmuş bir olgudur (Bingöl, 2014: 113). 
Tüm bunlar neticesinde kadınlar hem çalışma hayatı içerisinde hem de daha işe giriş aşamasında ayrımcılığa maruz kalmaktadır. İşe alımlarda işverenlerce öncelikli tercihin genellikle erkekler olması, kadınların erkeklere nazaran daha çok düşük ücretle alt kademe işlerde, yarı zamanlı işlerde çalıştırılması, ücret konusunda durumun erkekler lehine olması, kadınların hamilelik nedeniyle işten çıkarılması ve kadınların terfi imkânlarının kısıtlanması başlıca ayrımcılık örnekleridir. Kaldı ki kadınlar zaten aile hayatındaki rol ve sorumlulukları nedeniyle çalışma hayatında erkekler ile olan rekabetinde geriden başlamaktadır. Bu durum kadınların işe alımlarından terfilerine kadar çalışma hayatını etkilemektedir (İleri, 2016: 139).

Çalışma hayatındaki cinsiyet eşitliği politikaları ise kadın ve erkeklerin eşitliğini sağlama amacıyla meydana getirilen eşit istihdam, eşit işsizlik ve eşit ücret gibi politikalardır (Dedeoğlu, 2011: 3).

$\mathrm{Bu}$ bağlamda toplumsal cinsiyet eşitliği, her iki cinsin de cinsiyetlerinden bağımsız bir biçimde toplumsal alanda eşit hak, sorumluluk, imkân ve firsatlara sahip olması manasına gelmektedir. Toplumsal cinsiyet eşitsizliğinin kadınların çalışma hayatına yansımasına bakıldığında temel sorunun cinsiyete dayalı mesleki ayrımcılık olduğu görülmektedir. Bu konu, 2003 yılında yürürlüğe giren 4857 sayılı İş Kanunu'nun "eşit davranma ilkesi" başlıklı beşinci maddesinde ele alınmıştır. Ancak yapılan yasal düzenlemelere rağmen çalışma hayatında kadınların cinsiyet eşitsizliğinin süregeldiğini söylemek mümkündür (Gül vd., 2014: 171).

Kadınların işgücüne katılımı yasal açıdan desteklense de uygulamada sorunlar mevcuttur. Bu sorunlara ek olarak toplumsal cinsiyet gereği kadınlara atfedilen rol ve sorumluluklar nedeniyle aile yaşamındaki sorumluluklar ağırlıklı olarak kadınların üzerindedir. $\mathrm{Bu}$ doğrultuda kadınların aile yaşamındaki sorumlulukları çalışma hayatlarını etkilemektedir. Hatta bu durum zaman zaman kadınların çalısma hayatında yer almamayı tercih etmelerine ya da yer alamamalarına yol açmaktadır. Nihayetinde Türkiye'de kadınların işgücüne katılımlarının erkeklere nispeten çok daha düşük düzeyde olduğu bilinen bir gerçektir (Korkmaz ve Korkut, 2012: 45). Nitekim Türkiye İstatistik Kurumu'nun verileri neticesinde hane halkı işgücü araştırması sonuçlarına göre; 2019 yılında, Türkiye'de 15 ve daha yukarı yaştaki istihdam edilenlerin oranı $\% 45,7$ olup bu oranın kadınlarda $\% 28,7$, erkeklerde ise \%63,1 olduğu görülmektedir (TUIK, 2021).

\section{Kadınların Çalışma Hayatında Karşılaştıkları Sorunlar}

Kadınlar çalışma hayatına, çalışan, anne, eş ve ev hanımı olmak üzere birden çok kimlik ile katılırlar. Bu duruma çalışma hayatında cinsiyet ayrımcllı̆̆ının da eklemlenmesi ile birlikte "çalı̧an kadin sorunu" ortaya çıkmaktadır (Parlaktuna, 2010: 1229).

Nitekim kadınlar işe giriş aşamasından itibaren pek çok engelle karşılaşmakta ve engellerle dolu olan bu süreç işe girememelerine yol açabilmektedir. Öte yandan işe başladıktan sonra da cinsiyetleri nedeniyle kadınlar çeşitli sorunlarla mücadele etmek durumundadırlar. Genel hatlariyla bu sorunlar, toplumsal cinsiyete dayalı 
ayrımcılık, eğitimde eşitsizlik ve sosyo-kültürel engeller, ücretlendirmede eşitsizlik, hamilelik dönemleri, ev ve aile hayatlarında üstlenmeleri gereken roller (ev işleri, çocuk ve yaşlı bakımı), iş-aile çatışması, cam tavan engeli, cam uçurum, cinsel taciz, psikolojik taciz, sosyal güvenlik sorunu taşıyan işler ve enformel çalışma biçimleri şeklinde ifade edilebilir (Aksöz ve Eroğlu Durkal, 2021: 142-144).

Kadınların çalışmasına yönelik tutumlar, kadının eğitim seviyesi, medeni hali, sahip olduğu çocuk sayısı ve yaşları, eşinin eğitim seviyesi, kırsal alandan kente göç, ücret eşitsizliği, kadın istihdamını arttırmaya dair yasal düzenlemelerin yetersiz kalabilmesi gibi faktörler kadınların çalışma hayatına katılımında etkili olmaktadır (Korkmaz ve Korkut, 2012: 51-60).

$\mathrm{Bu}$ bağlamda kadın istihdamının düşüklüğünü tek bir sebebe bağlamak mümkün değildir. Aksine bu durum birbirine bağlı sebepler silsilesinden kaynaklanan çok boyutlu bir sorundur. $\mathrm{Bu}$ sebepler göz önünde bulundurulduğunda toplumsal cinsiyete dayalı iş bölümü, toplumsal değer yargıları, geleneksel aile yapısı, kadın emeğine talep yapısının zayıflığı, tarımsal üretim yapısındaki çözülme, kırdan kente göç, genel ve mesleki açıdan kadının düşük eğitim düzeyi, ekonominin istihdam hacminin düşük olması, kadının doğurganlığ1, annelik, çocuk ve hizmet bakımı, ev işleri gibi aile içi sorumlulukları, bu ev içi sorumlulukların daha çok kadında olması ve kurumsallaşamaması, kadının iş gücü piyasasına girmesinde etkili mekanizmaların gereken düzeyde olmayışı gibi pek çok sebep siralanabilir (Karabiy1k, 2012: 240-241).

$\mathrm{Bu}$ bağlamda cinsiyet etkenine bağlı olarak kadınların çalışma hayatında karşılaştıkları sorunlar, eğitim ve mesleki eğitimde eşitsizlik, iş bulma ve yükseltilmede eşitsizlik, ücretlendirmede eşitsizlik, sosyal haklardan yararlanmada eşitsizlik, cinsel taciz olmak üzere beş grupta toplanabilir (Kocacık ve Gökkaya, 2005: 206). Ancak tüm bunlara zemin harlayan temel problemin önceki başlıkta incelediğimiz cinsiyete dair ayrımcllık ve gelenekselleşmiş toplumsal cinsiyet olgusu olduğu söylenebilir.

Kadınların çalışma hayatında yer almalarının gerek bireysel gerek ekonomik gerekse toplumsal açıdan yarattığ tüm bu olumlu geri dönüşlere rağmen kadınlar günümüzdeki konumlarını elde etmek için daima bir mücadele içerisinde olmuşlardır. Günümüzdeki konumların bakıldığında yüzyıllar süren bu mücadelede belli bir konuma gelmiş olsalar da mücadelelerinin bittiğini söylemek hala daha mümkün değildir. Çünkü coğrafi olarak farklı şekillerde ve ölçülerde kendini gösterebilse de kadınlar çalışma hayatlarında pek çok sorunla karşı karşıya kalmaktadırlar. Bu sorunların başında cinsiyete dayalı ayrımcılık gelmektedir. Söz konusu bu sorun işe girmede ayrımcılık, terfide ayrımcilık ve cam tavan sendromu, ücretlendirmede eşitsizlik, belli sektörlerde ve mesleklerde yoğunlaşma gibi çeşitli başka sorunları da beraberinde getirmektedir. Bu nedenle kadınların işgücüne katılımlarının pozitif geri dönüşleri göz önüne alındığında mesleki cinsiyete dayalı ayrımcillk irdelenmesi gereken önemli bir problem haline gelmiştir. Bu doğrultuda kadınların çalışma hayatına katılımlarının arttırılması ve konumlarının iyileştirilmesi 
adına çalışmalar yapılması, kadınlara yönelik istihdam politikalarının geliştirilmesi gerekmektedir (Parlaktuna, 2010: 1217).

Kadınların çalışma hayatından soyutlanmaları, esasında eğitim ve meslek edinme konusundaki firsat eşitsizliği ile birlikte başlamakta, işe giriş, ücret, terfi, işten çıkarılma gibi konulardaki ayrımc1 tutumlar ile devam etmektedir. Gerek kadınların eğitim ve meslek edinmedeki firsat eşitsizliği nedeniyle gerekse de cinsiyete dayalı ayrımcı yaklaşımlardan ötürü çalışma hayatında erkeklerin gerisinde kalmaları, hayatın diğer alanlarında da sorunlara ve engellere yol açmaktadır. Böylece kadınlar sendikalarda, sivil toplum kuruluşlarında yerel yönetimlerde ve ulusal siyasette, toplumsal alandaki azımsanamayacak sayısal ağırlı̆̆ına rağmen yeterince yer alamaz ve temsil edilemez (Çakır, 2008: 42). Bu durum ise kadınların sorunlarının istenen düzeyde çözülememesine yol açarak kısır bir döngü halini alır. Dolayısıyla söz konusu sorunların yalnızca çalışma hayatına dair sorunlar olarak görülmesi kadının sosyal bir birey olmasını göz ardı edecek kadar sı̆̆ bir bakış açısıdır. Zira kadınların ekonomik, toplumsal ve siyasal statüleri ve güçleri birbirini besleyen sebep sonuç ilişkisine dayanan bir ağdır.

Netice itibariyle çalışma özelinde kadınların genelde ise toplumdaki tüm bireylerin her ortamda ve her koşulda insan haklarından eşit bir biçimde faydalanması gerekir. Fakat kadınlar, toplumda çeşitli alanlarda cinsiyet ayrımcılığına maruz kalmaktadırlar. Bu alanlardan önemli bir tanesinin de çalışma hayatıdır. Oysaki çalışma kadınların çalışma hayatına dâhil olması ile birlikte kendilerine, topluma ve ülke refahına katkılarının önemi aşikârdır. Hal böyleyken ülkelerin yasal düzenlemeleri ve sosyal politikaları aracilı̆̆ıla kadınların çalışma hayatında korunması, dezavantajlı konumunun giderilmesi, cinsiyetine özgü koşullarına göre bir takım kolaylık sağlanması gerekmektedir. Bu doğrultuda çalışma kapsamında ilk olarak Anayasal temeldeki çalışma hayatında kadınlara yönelik düzenlemeler ardından İş Kanunu'ndaki düzenlemeler detaylı olarak ele alınacaktır.

\section{Kadın Çalışanları Korumaya Yönelik Ulusal Yasal Düzenlemeler}

Bu başlık altında öncelikli olarak Anayasa'da çalışan kadınları korumaya yönelik hükümler ele alınmış daha sonra da Anayasal dayanaktan hareketle 4837 Sayılı İş Kanunu'nda (2003) koruyucu düzenlemeler irdelenmiş ve genel bir değerlendirmeye tabi tutulmuştur.

\section{Anayasal Düzenlemeler}

Anayasa normlar hiyerarşisinin en tepesinde yer almaktadır. Devletin temel kuruluşlarına ve vatandaşların temel hak ve özgürlüklerine dair düzenlemeler Anayasa'da yer almaktadır. Zira kanunlara nispeten değiştirilmesi daha zor olan hukuk kurallarıdır (Gözler ve Kaplan, 2016: 36). Anayasa ile vatandaşların temel 
hak ve özgürlükleri güvence altına alınmış bu haklarının yanı sıra sosyal ve ekonomik haklarının sınırı da belirlenmiştir (Özbudun, 2005: 103).

Çalışan kadınlar açısından bakıldığında da koruyucu nitelikteki en genel hüküm Anayasa'nın 10. maddesinde "Kanun Önünde Eşitlik İlkesi” başlı̆̆1 ile yer almaktadır. Bu maddeye göre "Herkes, dil, ırk, renk, cinsiyet, siyasi düşünce, felsefi inanc, din, mezhep ve benzeri sebeplerle ayırm gözetilmeksiz̨in kanun önünde eşittir." 2004 y1linda Anayasa'da yapılan düzenleme ile "Kadinlar ve erkekler esit haklara sabiptir. Devlet, bu eşitliğin yaşama geçmesini sağlamakla yükümlüdür. Bu maksatla alınacak tedbirler eşitlik. ilkesine aykırn olarak yorumlanamaz: " ifadesi eklenmiştir. Böylelikle kadınların erkekler ile eşit haklara sahip olduğu Anayasa ile güvence altına alınmış, dahası bu eşitliğin hayata geçirilmesi hususunda devlet sorumlu kılınmıştır. Bu doğrultuda da alınacak tedbirler ile kadınlar için pozitif ayrımcılığın yasal dayanağı oluşturulmuştur. Anayasaların bir nevi devletlerin kimliklerini temsil etmesinden dolayı, 1982 tarihli Anayasa'da kadın erkek eşitliğinin ifade edilmesi oldukça önemlidir (Anayasa, 1982, Madde 10; Gözler ve Kaplan, 2016: 36).

Böylece Anayasa’ya göre herkes ayrım gözetilmeksizin kanun önünde eşittir. Kadınlar ve erkekler eşit haklara sahiptirler. Devlet, bu eşitliğin yaşama aktarılmasını sağlamakla yükümlüdür (Çelik, Caniklioğlu, Canbolat, 2020: 435).

Anayasa madde 49'da "Calışma hake. ve ödevi” başlı̆̆1 altında çalışmanın herkesin hakkı ve ödevi olduğuna dair ifade çalışmanın erkekler kadar kadınların da Anayasal bir hakkının olduğunun göstergesidir. Anayasa'nın 50. maddesini düzenleyen "Calışma şartlar ve dinlenme hak.ke." başlı̆̆ına göre; "Kimse, yaşına, cinsiyetine ve gücüne uymayan işlerde çalıstırlamaz. Küçükler ve kadınlar ile bedeni ve rubi yetersizliği olanlar çalısma şartlar bakımından özel olarak korunurlar. Dinlenmek, çalışanların bak.kidır. Ücretli hafta ve bayram tatili ile ücretli yullik izin haklar ve sartlar kanunla düzenlenir." Böylece kadınların çalışma şartları açısından özel olarak korunacağ1, kendisine uymayacak işlerde çalıştırılamayacağı ve ücretli izinlerinin kanun esası ile düzenleneceği öngörülmüştür. Anayasa'nın “Ücrette adalet sağlanmasi” başliklı 55. maddesine göre ise "Ücret emeğin karsıllĭglır. Devlet, çalısanlarn yaptıklar ise uygun adaletli bir ücret elde etmeleri ve diğer sosyal yardimlardan yararlanmalar için gerekli tedbirleri alır." Söz konusu maddeden de anlaşıldığı üzere devlet, çalışanların yaptıkları işe göre ücret kazanmaları hususunda yükümlü kılınmıştır. Bu doğrultuda kişiye göre ücrete dair farklı uygulama yapılmaması ve herkese eşit davranılması gerekli görülmüştür.

\section{Türk İş Hukukunda Çalışan Kadınları Korumaya Yönelik Düzenlemeler}

İş Hukuku'nda kadınları korumaya yönelik başlıca düzenlemeleri eşitlik ilkesi ve ayrımcılık yasağı, kadın işçileri çalıştırma yasağı, hamilelik ve analık durumunda kadın işçilerin sahip olduğu haklar, tacize karşı kadın işçileri koruyan düzenlemeler ve kıdem tazminatı bakımından kadın işçilerin hakları olarak sıralamak mümkündür. Bu başlık altında sırası ile söz konusu düzenlemeler ele alınmıştır. 


\section{Eşitlik İlkesi ve Ayrımcılık Yasağı}

Anayasa'nın "Kanun önünde eşitlik" başlı̆̆1 altında yer alan 10. maddesine paralel olarak 4857 sayılı İş Kanunu'nda "Eşit davranma ilkesi" başlığı altında 5. madde ile iş ilişkisinde eşitlik ilkesi ele alınmıştır. Bu madde ile işverenin, işçiye karşı eşit davranma borcu ve bu yükümlülüğü yerine getirmediği takdirde karşılaşacağ1 yaptırımlar ifade edilmiștir (Aslan Ertürk, 2017: 354).

İş hukukunda eşitlik ilkesi, esasen işveren açısından bir yükümlülüktür. Bu durumun yasal kaynaklarının başında Anayasa'nın 10. maddesinin gelmesinin yanı sıra 6701 sayllı Türkiye İnsan Hakları ve Eşitlik Kurumu Kanunu da eşitlik ilkesinin bir diğer yasal dayanağını oluşturmaktadır (Çelik, Caniklioğlu, Canbolat, 2020: 435). Böylelikle işverenin, işçilerine ya da iş başvurusunda bulunan adaylara karşı hiçbir ayrım gözetmeksizin eşit davranma borcu İş Kanunu'nda bizzat düzenlenmiştir (Akyiğit, 2020: 207).

İş kanunu kapsamında kadın çalışanlan korumaya yönelik düzenlemeleri sırası ile işe girme ve çalışma koşullarında eşitlik, ücrette eşitlik ve kıdem tazminatı hususunda eşitlik olarak ele almak konunun anlaşılması adına daha doğru olacaktır.

İlk olarak iş ilişkilerinde ayrımcılık yapılamayacağına dair hükmü incelediğimizde aynı konumdaki işçiler arasında ayrım yapılamayacağı ve farklı muamelelerde bulunulamayacağının ifade edildiğini görmekteyiz. Bu doğrultuda İş Kanunu 5. maddenin 1. fikras1 uyarınca; "İs ilişkisinde dil, ırk, renk, cinsiyet, engellilik, siyasal düsü̈nce, felsefí inanc, din ve mezhep ve benzeri sebeplere dayah ayrm yapulamaz" ifadesi ve aynı maddenin 2. fikrası uyarınca "İsveren, esash sebepler olmadlkeça tam süreli çalşsan

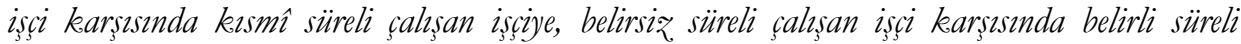
çalşan işsciye farkh işlem yapamaæ:" ifadesi hükme bağlanmıştır. İş Kanunu 5. maddenin 3. fikrası ile ise daha da özele inilerek kadınların biyolojik nitelikleri gereği ayrımcılığa maruz kalmalarının önüne geçilmek istenmiştir. Bu hükme göre "İsveren, bijolojik veya işin niteligine ilişkin sebepler zorunlu kalmadiksa, bir ișçiye, is sözleşmesinin yapulmasinda, șartlarmm olusturulmasinda, uygulanmasinda ve sona ermesinde, cinsiyet veya gebelik nedeniyle doğrudan veya dolayl farkli ișlem yapama:"

İlgili hükmü bir örnek üzerinden açıklamak gerekirse, birden fazla sayıda eleman alınacak bir işyerinde, aranan niteliklere uygun birçok kadın adayın bulunmasına rağmen tüm işe alınanların yalnızca erkeklerden oluşması halinde açık bir şekilde cinsiyete dayalı ayrımcılıktan söz edilebilir. Bir başka önemli örnek ise kadın işçi adaylarına yöneltilen hamilelik sorularıdır. İş başvurularının değerlendirilmesi sürecinde işveren, kadın adaylara hamile olup olmadıklarını veyahut ileride çocuk sahibi olmayı düşünüp düşünmediklerini sorabilmektedir. $\mathrm{Bu}$ doğrultuda çoğu işveren, hamile veya çocuk sahibi olmayı planlayan kadın adaylarla çalışmayı istememektedir. Çünkü kadın adayları hem hamilelik dönemlerinde iş performanslarının düşme ihtimali hem de doğum ve analık izni sebepleri ile daha maliyetli işgücü olarak görmektedirler. İşverenin her ne kadar bilgi toplama hakkı olsa da doktrinde, hamileliğin kadınlara özgü bir durum olması nedeniyle bu konudaki sorunların cinsiyet ayrımcilı̆ı meydana getirdiği kabul edilmektedir (Yuvalı, 2003: 96). 
İş kanunu 5. maddenin 3. Fıkrasının dikkat çekici bir özelliği ise işverenin kadın işçiye yönelik cinsiyet veya gebelik nedeniyle ayrımcılık yapması verilen örneklerde olduğu gibi doğrudan olmasının yanı sıra ilk bakışta fark edilemeyecek ancak sonuçları göz önüne alındığında ayrımcıllğın var olduğu anlaşılacak bir biçimde dolaylı olarak da yapılabilir. Söz konusu maddeye dair önemli bir diğer husus ise hükme yine aynı madde ile istisna getirilmesidir. Daha açık bir ifade ile "İsveren, biyolojik veya işin niteliğine ilişkin sebepler zorunlu kulmadıkça" ibaresi gereği biyolojik veya işin niteliğinden kaynaklanan bir sebep neticesinde işveren, kadın işçi yerine erkek işçi almayı tercih edebilir. Örneğin genel itibariyle beden gücüne dayalı bir iş için kadın işçi yerine erkek işçinin alınması sonucu işveren eşit davranma yükümlülügüne aykırı hareket etmiş olmayacaktır (Oğuz, 2018: 572).

İkinci olarak İş Kanunu'nun 5. maddesi ile ücret konusunda da eşitlik ilkesini esas aldığını ve kadın işçileri korumaya yönelik bir düzenleme içerdiğini görmekteyiz. Bu doğrultuda sırf cinsiyetleri nedeni ile kadın işçilerin, erkek işçilerden daha az bir ücret ödenmemesi gözetilmiştir. Nitekim söz konusu madenin 3. ve 4. fikraları gereğince "Ayn veya eşit değerde bir iş için cinsiyet nedeniyle daha düssük ücret kararlasttrilamaz. Isscinin cinsiyeti nedeniyle özel koruyucu bükümlerin uygulanması, daha düsük bir ücretin uygulanmasin hakh kılmą:” Söz konusu hükümler itibariyle aynı veya benzer işi yapan kadın ve erkek işçiler arasında cinsiyetten ötürü ücrette farklılık olmayacak ve aynı ücreti alacaklardır. İş Kanunu madde 5'in yanı sıra, madde 74 ile de ücret konusunda kadınlar korunmuştur. İş kanunu 74.

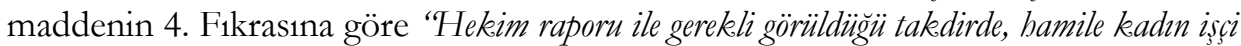

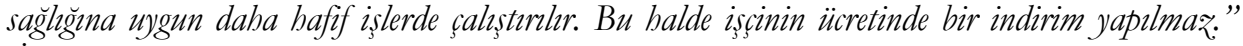
(İs kanunu, 2003, Madde 5).

Yüzyllardır gerek biyolojik nedenler sebep gösterilerek gerek geleneksel, toplumsal ve eğitim seviyesi gibi nedenlerden ötürü kadınlar erkeklere nispeten çalışma hayatında daha az ve zor yer bulabilmiş ve ucuz işgücü olarak görülmüşlerdir. Bu nedenle kadınların ücret haklarının yasal bir dayanağının olması oldukça önemli bir meseledir (Yuvalı, 2003: 100). Ancak uygulamada da işlerin aynı şekilde ilerleyip ilerlemediği günümüzde bile oldukça belirsiz bir konudur.

Üçüncü olarak İş Kanunu'nun 5. maddesinin kadınları korumaya yönelik son düzenlemesi ise ayrımcılık tazminatıdır. Bu düzenleye göre kadın işçilere sırf cinsiyetlerinden ötürü farklı muamele gösterilmesi veya düşük ücret ödenmesi sonucu eşit davranma yükümlülügünün ihlali halinde, işverene yaptırım öngörülmüş ve işverenin işçiye tazminat ödemesi esas kılınmıştır. Nitekim İşs Kanunu'nun 5. maddesinin 6. fikrasina göre 'İs iliskisinde veya sona ermesinde yukardaki fikera bükü̈mlerine aykur davramldiğında iş̧̧i, dört aya kadar ücreti tutarndaki uygun bir tą̧minattan başka yoksun bırakıldrğg baklarm da talep edebilir." Sonuç itibari ile İş Kanunu madde 5 ile eşit davranma borcu düzenlenmiş, işe giriş ve çalışma koşulları, ücret ve iş sözleşmesinin feshi konularında işverene eşit davranma yükümlülüğü getirilmiştir. 


\section{Kadın Iş̧̧ileri Çalıştırma Yasağı}

İş Kanunu kadınların fiziksel özellikleri doğrultusunda kadın işçileri korumaya yönelik bazı hükümler içermektedir. Bu hükümler kaynağını kimsenin yaşına, cinsiyetine ve gücüne uymayan bir işte çalıştırllamayacağına dair Anayasanın 50. maddesinden almaktadır. Bu doğrultuda kadınlar cinsiyetlerin elvermediği işlerde çalıştırılmayacak ve çalışma şartları açısından korunacaktır. Bu durumun arkasındaki sebep kadınların fiziksel ve biyolojik yapıları gereği bazı işlerde çalışamamalarıdır. İş kanununda yer alan kadınları korumaya yönelik bu hükümlerin kadınlara yönelik ayrımcılık veya çalısma özgürlüklerinin kısıtlanması olarak düşünülmemesi gerekmektedir. Aksine bu hükümler kadınların çalışmasını kısıtlamak için değil fiziksel ve biyolojik yapıları gereği çalışması uygun olmayacak işler hususunda onları korumaya yöneliktir. İş Kanunu'nun öngördüğü koruyucu nitelikteki bu düzenlemeler, sırası ile yer ve su altı işlerde çalıştırma yasağı, gece çalıştırma yasağı, ağır ve tehlikeli işlerde çalıştırma yasağı, hamilelik ve doğum halinde çalıştırma yasakları veya ücretsiz izin istemeye ilişkin kurallar olarak karşımıza çıkmaktadır (Yuvalı, 2013: 103; Oğuz, 2018: 575).

İş Kanunu'nun 72. maddesi ile bu madde kapsamında sayılan işlerde her yaştaki kadının çalıştırılması yasaklanmış, kanunun 73. Maddesi ile sanayie ait işlerde 18 yaşını doldurmamış olan kadın işçilerin gece çalıştırılması yasaklanmıştır. Ayrıca Çocuk ve Genç İşçilerin Çalıştırılma Usul ve Esasları Hakkında Yönetmelik uyarınca sanayie ait olup olmama ayrımı olmaksızın 18 yaşını doldurmamış olan çocuk ve genç işçilerin gece çalıştırılmaları yasaklandığ için doğal olarak 18 yaşını doldurmamış olan kadın işçilerin de gece çalıştırılması yasaktır (Mollamahmutoğlu, Astarl, Baysal, 2019: 88). Söz konusu bu düzenlemeler ile daha iş ilişkisinin kurulması sırasında kadın işçilerin korunması sağlanmıştır.

\section{Yer ve Su Altında Çalıştırma Yasağı}

4857 sayll İş Kanunu madde 72 uyarnnca "Maden ocaklar ile kablo döşemesi, kanalizasyon ve tünel insaatı gibi yer altunda veya su altında çalssılacak işlerde on sekiz yassm doldurmamıs erkek ve her yaștaki kadinlarn çalıştrilmasi yasaktır." İş Kanunu'nun "İşin düzenlenmesine ilişkin bükümlere aykurllk" başlıklı 104. maddesine göre, yer ve su altında çalışırma yasağına aykırı hareket eden işveren ya da vekiline idari para cezası yaptırımı uygun görülmüştür. Bununla birlikte yasak kapsamındaki işlerde çalıştırılan kadın işçiler çalıştığı süre zarfindaki haklarından faydalanmalıdır (Yuvalı, 2013: 104; Kurt, 2018: 67).

\section{Gece Çalıştırma Yasağı}

Gece postalarında çalışılması işçi sağlığının daha sık ve yoğun olarak bozulmasına, yorgunluğa, daha sık bir biçimde iş kazalarına, aile düzeninin bozulmasına, eş ve çocuklara yeterince zaman ayıramama sorunlarına, iletişim kopukluğuna, sosyal çevreden soyutlanmaya ve ilişkilerin zayıflamasına yol açmaktadır (Yılmaz, 2018: 8788). Bu nedenle özellikle aile ilişkilerine dayalı sorunlar göz önüne alındığında kadınların gece postalarında çalışmalarına dair özel düzenlemelerin getirilmesi gerekli görülmüştür. 
İş Kanunu'nda kadınların gece postalarında çalışmalarına dair bir düzenleme de söz konusudur. Kanununun "Gece çalsştırma yasağı” başlıklı 73. maddesi gereğince "Sanayie ait işlerde on sekiz yaşım doldurmamıs çocuk ve genc işscilerin gece çalsştrrlması yasaktır. On sekiz yașm doldurmus kadm ișçilerin gece postalarnnda çalnștırlmasina ilişkin

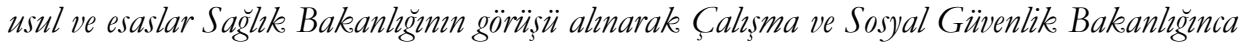
hazırlanacak bir yönetmelikte gösterilir." Nitekim söz konusu madde ile sanayie ait işlerde on sekiz yaşını doldurmamış kadın işçilerin çalışması yasaklanırken, on sekiz yaşını doldurmayanların gece postalarında çalıştırılmaları "Kadın Calışanların Gece Postalarnda Calsstırlma Kosullar Hakeknda Yönetmelik" (2013, Sayl: 28717) kapsamında bazı kurallara tabi tutularak izin verilmiştir (Demircioğlu ve Centel, 2016: 83).

Söz konusu yönetmelik on sekiz yaşını doldurmuş kadın işçilerin sanayiye ait işlerde çalışmaları konusunda herhangi bir yasak getirmemekte ancak belli şartlar sunmaktadır. Bu doğrultuda yönetmeliğin 5. maddesine göre "Kadin çallşanlar her ne şekilde olursa olsun gece postasinda yedi buçuk saatten fą̧ la çalıstırlamaz:" Yönetmeliğin 6. maddesinde gece postalarında çalışan kadınlar için işveren işyerine ulaşım konusunda yükümlü k1lınmıştır. Bu maddeye göre "Belediye smorlar dişındaki her türlü isyeri issverenleri ile belediye simrlar içinde olmakla beraber, posta değgsisim saatlerinde toplu taşıma araçlar ile gidip gelme zorluğu bulunan isyeri işverenleri, gece postalarnda çalşstracaklar kadin çalışanlar, sağlayacaklar uygun araçlarla ikametgâblarna en yakin merkę̧den, isyerine götürüp getirmekle yükkümlüdür." Yönetmeliğin 7. maddesi ile sağlık gözetimi şartı getirilmiştir. İlgili maddenin 1. fikrasına göre "Kadın çalışanlarn gece postalarnda çalşstrrlabilmeleri için, işe başlamadan önce, gece postalarnda çalsstrrlmalarinda sakinca olmadiğna ilişkin sağglk raporu isyerinde görevli isyeri hekiminden almur." 8. madde de ise yine kadın çalışanlara kolaylık sağlama adına kadının eşinin de gece postasında çalışması durumunda, işveren çalışma saatlerini kadın işçinin isteği doğrultusunda hazırlar. Nitekim maddeye göre "Kadin çalsşanm kocası da işin postalar halinde yürütüldü̈̆̈ aym veya aym bir isyerinde çalsşyor ise kadm çalşanm isteği üzerine, gece çalşstmlması, kocasinn çalısttğg gece postasma rastlamayacak, şekilde düzenlenir. Ayn isyerinde çalışan eşlerin aym gece postasinda çalıs̆ma istekleri, işverence, imkân dabilinde karşılanır. "Söz konusu yönetmeliğin 9. maddesi gebe ve emziren kadınların çalıstırılma yasağına dair hükümler içerir. Madde 9'a göre 'Kadnn çalşsanlar, gebe olduklarmnn doktor raporuyla tespitinden itibaren doğuma kadar, emə̧iren kadin çalş̧anlar ise doğum taribinden başlamak üzere kendi mev₹uatlarndaki bükümler sakl kalmak kaydyyla bir yul süre ile gece

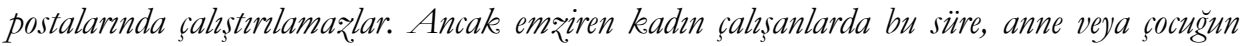
sağhlğ açısından gerekli olduğ̈unun isyerinde görevli isyeri hekiminden alnan raporla belgelenmesi halinde altı ay daha uzatılir. Bu çalişanlarn anulan sürelerdeki çalısmalar, 14/7/2004 taribli ve 25522 saynl Resmî Gazete'de yaymlanan Gebe veya Emziren Kadinlarm Callsturlma Sartlaryla Emæirme Odalar ve Cocuk Bakum Yurtlarna Dair Yönetmelik bükümleri sakh kalmak üzere gündüz postalarna rastlayacak şekilde düzenlenir." 


\section{Hamilelik ve Analık Halinde Kadın Iş̧̧ilerin Hakları}

Kadın işçinin hamileliğinin, işe başlamadan veya işe girip çalışmaya başladıktan sonra gerçekleşmesi fark etmeksizin, bu hamilelik döneminde ve doğum sonrası analık halinde kadın işçinin belli ölçüde izne tabi olması gerekir. Bu sebeple verilen izne doğum ižni veya anahk iæ̌ni denilmektedir (Akyiğit, 2020: 445).

Doğum ve lohusalık dönemi, kadın işçi açısından gerek fiziksel gerekse de psikolojik bakımdan farklı etkiler yaşadıkları özel bir dönemdir. Kaldı ki bir de bu duruma bebeğin doğumu sonrası anne ile bebek arasındaki ilişkinin sağlıklı kurulması, bebeğin bakımı ve gelişimi için anneye ihtiyaç duyması annenin bebek ile özel olarak zaman geçirmesi gereksinimini ortaya ç1karmaktadır. 6663 sayılı Kanunla 2016 yılında İş Kanunu'nda bazı değişiklikler yapılmadan önce bu konu yalnızca sağlık açısından ele alınmış ve doğumdan önce ve sonra sekizer hafta kadın işçinin çalışırılması yasaklanmıstır. Fakat 6663 sayılı Kanun ile bu çalıştırma yasağının haricinde kadın ve erkek işçiye ayrıca üç yaşından küçük çocuğu evlat edinenlere yeni bir takım haklar tanınmıştır (Çelik, Caniklioğlu, Canbolat, 2020: 820).

İş Kanunu'nda, kadınların hamilelik ve analık dönemlerinde ILO Sözleşmeleri doğrultusunda korunmalarına yönelik özel düzenlemeler yapılmış ve gerekli önlemler alınmıştır. Kadın işçilerin İş Kanunu'nda hamilelik ve analık durumunda korunmasına ilişkin düzenlemeler sırası ile doğumdan önceki ve sonraki koruma, analık halinde süt izni ve analığ koruyucu diğer hükümler olmak üzere düzenlenmiş bulunmaktadır (Taşkent ve Kurt, 2014: 40-43).

Kadınların doğumdan önce ve sonra korunmasına yönelik olarak İş Kanunu'nun 74. maddesinin 1. fikrasında doğum izni öngörülmüştür. Bu madde uyarınca "Kadin işscilerin doğumdan önce sekiz, ve doğumdan sonra seki₹ hafta olmak ǚrere toplam on altı haftalı. süre için çalıstırlmamalar esastır. Coğul gebelik. halinde doğumdan önce çalsstırlmayacak sekiz, haftallk süreye iki hafta süre eklenir. Ancak, sağllk durumu uygun olduğu takdirde, doktorun onayn ile kadn iş̧̧i isterse doğumdan önceki $\ddot{u} c$ haftaya kadar isyerinde çalışabilir. Bu durumda, kadn ișcinin çalıștığ süreler doğum sonrası sürelere eklenir. Kadin işşinin erken doğum yapması halinde ise doğumdan önce kullanamadiğ çalıştrilmayacak süreler, doğum sonrası sürelere eklenmek suretiyle kullandirllr." Nitekim söz konusu kanun hükmü ile en basit haliyle kadın işçilere toplamda 16 haftalık ücretsiz doğum izni tanınmıştır. Çoğul gebelik durumunda ilave 2 hafta söz konusudur. Ayrıca sağlık durumunun elvermesi durumunda doğumdan önceki üç haftaya kadar çalışabilen kadınlara kolaylık sağlanarak izin haklarını doğum sonrasında kullanabilme imkânı sunulmuştur. Böylece verilen sürelerin kullanım biçimi sabit olmayan süreler olduğu esas olanın kadının isteği ve doktorun onayı olduğu böyle bir durumda işverenin inisiyatifinin olmadığı oldukça aşikardır. Dahası erken doğum ihtimali de göz ardı edilmemiş ve kadınların hakları bu hususta da korunmuştur.

Yine İş Kanunu'nun 74. maddesinin 3-6. fikralarına göre 'Yukarda öngörülen süreler işcinin sağllk durumuna ve işin özelliğine göre doğundan önce ve sonra gerekirse arturlabilir. Bu süreler hekim raporu ile belirtilir. Hamilelik süresince kadn isçiye periyodik. 
kontroller için ücretli iz̨in verilir. Hekim raporu ile gerekli görüldügü takdirde, hamile kadin iş̧i să̆llğına uygun daha hafif işlerde çalıstırlır. Bu halde iş̧̧inin ücretinde bir indirim yapulmaz: Isteği halinde kadın işçiye, onaltı haftalık sürenin tamamlanmasindan veya çoğul gebelik halinde onsekiz haftalı süreden sonra altı aya kadar ücretsiz iz̨in verilir. Bu ižin, üc yasım doldurmamıs çocuğu evlat edinme hâlinde eslerden birine veya evlat edinene verilir. Bu süre, yullik ücretli iz̨in hakkemm hesabında dikkate almmaz:" Söz konusu hüküm emredici niteliktedir. Dolayısıyla kadın işçinin ücretli iznini kullandıktan sonra ücretsiz izin talep etmesi halinde işveren izni vermek zorundadır. Bu hususta madde göz önünde bulundurulduğunda işverenin izni verip vermemeye dair takdir hakkının olmadığı gayet açıktır (Çelik, Caniklioğlu, Canbolat, 2020: 824). Böylece kadın işçilerin hamilelik dönemlerinde ve doğumdan itibaren belirli bir süre içerisinde tanınan izinler ile hem annenin hem de çocuğun sağlığının korunması hedeflenmiştir (Oğuz, 2018: 579). Zira İş Kanunu'nun 104 maddesi ile 74. maddedeki hükme bağlı kalmayarak, doğumdan önce ve sonraki sürelerde gebe veya doğum yapmış kadınları çalıştıran veya ücretsiz izin vermeyen işveren veya vekiline idari para cezası öngörülür.

İş Kanunu 74. madde ile kadınları analık halinde özel olarak korumaya yönelik başka bir hüküm ise kadınlara tanınan süt izni hakkıdır. Maddenin 7. fikrası uyarınca "Kadın iş̧ilere bir yaşından kü̧̈ük çocuklarmm emzirmeleri için günde toplam bir bucuk saat süt izni verilir. Bu sürenin hangi saatler arasında ve kaça bölünerek kullanılacağın iş̧̧ kendisi belirler. Bu süre günlük çalısma süresinden saynlır.” Bu düzenleme ile kadın işçinin çocuğu ile yakından ilgilenmesi hedeflenmiştir. Bu nedenle kadın işçi herhangi bir nedenden ötürü çocuğunu emziremezse bile bir buçuk saatlik iznini kullanmasına işveren engel olamaz, bu izni kullandırması gerekir (Oğuz, 2018: 583). Hükme göre bu izin günlük olarak toplamda bir buçuk saat şeklinde kullanılacaktır. Ancak bazı iş yerlerinde kadınların her gün bu izni kullanmak yerine izinlerini biriktirerek toplu bir şekilde kullanmaya yönelik talepleri olabilmektedir. Eğer işveren bunda bir sakınca görmez ve uzlaşırlarsa kadınlar süt izinleri toplu olarak kullanabileceklerdir. Fakat söz konusu talep kanunun amac1 ve mantı̆̆1 ile uyuşmamakta ve işverenin böyle bir talebi kabul etme yükümlülüğü bulunmamaktadır. Süt iznine dair dikkat çeken bir diğer husus ise kanunda bu konunun yaptırımı ile alakalı bir boşluk olmasıdır. Nitekim 104. maddede gebe ve doğum yapmış kadınları çalıştıran veya ücretsiz izin vermeyen işveren için idari para cezası öngörülmüş iken süt iznini vermeyen işveren hakkında herhangi bir yaptırım öngörülmemiştir (Taşkent ve Kurt, 2014: 42-43). Ayrıca süt izni verilmeyip kadın işçinin bu izin süresinde çalıştırılması durumunda fazladan çalışma meydana gelecektir ki kadın işçiye bu fazla çalışma süresi karşılığında ödemenin yapılması gerekip gerekmediği de tartış1lmaktadır (Akyiğit, 2020: 448).

Tüm bunlara ek olarak gebe veya emziren kadınlar hakkındaki koruyucu bir başka düzenleme "Gebe veya Emziren Kadınların Calıştırlma Şartlaryla Emzirme Odalar ve Cocuk Bakım Yurtlarna Dair Yönetmelik"tir. 2013 y1lında yürürlüğe giren yönetmelik, 20/6/2012 tarihli ve 6331 sayılı Isş Sağlı̆̆1 ve Güvenliği Kanunu 
kapsamındaki kadın çalışan çalıştıran işyerlerine uygulanır (İlgili Yön.,m.2) ve İş Sağllğ1 ve Güvenliği Kanununun 30. maddesine dayanılarak hazırlanmıştır (İlgili Yön.,m.3).

Yönetmeliğin 8. maddesine göre "Kadmn çalısanlar, gebe olduklarmm sağglke. raporuyla tespitinden itibaren doğuma kadar geçen sürede gece çalısmaya zorlanamazlar. Yeni doğum yapmıs çalısanon doğumu iəleyen bir yol boyunca gece çalıstırlması yasaktır. Bu sürenin sonunda sağhlk ve güvenlik açısindan sakincal olduğunun sağhle raporu ile belirlendiği dönem boyunca gece çalıstrnlma₹:" Ayrıca ilgili yönetmeliğin 9. maddesine göre, "gebe veya

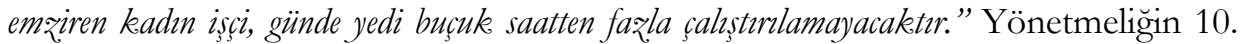
maddesi ile analık ve süt izni konusunda İş Kanunu'nun 74. maddesinin uygulanacağı ifade edilmiştir. Yönetmeliğin 11. maddesi ile gebe çalışanın muayene izni düzenlenmiş ve gebelik süresince, periyodik kontrolleri için gebe işçilere ücretli izin verileceği hükmedilmiştir. 12. maddeye göre ise "Emə̧iren çalışanlarn, doğum ižninin bitiminde ve işe başlamalarndan önce, çalıșalarnna engel durumlar olmady̆gnmn raporla belirlenmesi gerekir. Callsmasinn sakincalı olduğu hekim raporu ile belirlenen çalssan, raporda belirtilen süre ve işlerde çalşstrrlamaæ: "Son olarak bu yönetmeliğin 13. maddesi ile 100150 kadın iş̧̧inin çalıştırıldığı işyerlerinde, emziren çalışanlar için çalışma yerlerinden ayrı ve işyerine en fazla 250 metre uzaklıkta bir emzirme odasının kurulması zorunlu kılınmıştır. Eğer işyerinde çalışan kadın işçi sayısı 150'den fazla ise kadın işçilerin çocuklarını emzirebilmeleri ve 0-6 yaş arasındaki çocuklarının bakımını yapabilmeleri adına işveren çalışma yerinden ayrı ve işyerine yakın bir yurt kurmakla yükümlüdür. Söz konusu yurdun işyerine 250 metreden uzak olması halinde işveren taşıt ile ulaşım sağlamalıdır. Belirtmek gerekir ki yurt açılması için gerekli olan kadın işçi sayısına, annesi hayatta olmayan ya da velayeti annesine değil kendisine verilen babalar da eklenir (İlgili Yön. m.13).

\section{Kadın Iş̧̧ileri Tacize Karşı Koruyan Düzenlemeler}

Bu başlık altında özelde çalışma kapsamında kadınlar genel itibariyle ise işçilerin iş yerlerinde maruz kaldıkları cinsel taciz ve psikolojik taciz sorunlarının İş Kanunu kapsamında değerlendirilmesine değinilmiştir.

\section{Iş Kanunu Kapsamında Cinsel Taciz}

Cinsel taciz, gündelik yaşam içerisinde maalesef ki her alanda karşı karşıya gelinen bir problemdir. Tarihsel seyir içerisinde yapılan çalışmalar cinsel tacizin iş ortamında da sıklıkla orta çıktığını saptamıştır (Mimaroğlu ve Özgen, 2008: 321). İş yerinde cinsel taciz ile çalışma hayatında yaşanılması istenmediği halde karşılaşılan insan onurunu zedelemeye yönelik sergilenen her çeşit cinsel ima, söz ve davranış şeklidir. İş yerinde işverenin veya yöneticinin yönelttiği taciz türü, cinsel taciz bir çalışma suçudur. Çünkü iş yerinde cinsel taciz, işin devamını tehlikeye atmakta, mağdur çalışanın, çalışma hak ve özgürlüğünü, ekonomik özerkliğini ihlal etmektedir (Bakırc1, 2006: 159).

Cinsel taciz, cinsel temele dayalı ve istenmeyen davranışlar olarak tanımlanabilmekte ve iş yerinde bizzat işveren tarafından uygulanabilmesinin yanı 
sıra işveren vekili, başka bir işçi veya müşteri gibi üçüncü bir kişi tarafından gerçekleştirilebilir (Süzek, 2017: 440).

İş yerinde cinsel taciz sorunu, ekonomik, toplumsal ve psikolojik etkileri olan çok boyutlu bir sorundur. Sanayi Devrimi ile birlikte çalışma hayatında varlık gösteren kadınlar açısından cinsel taciz devamlılı̆̆ olan bir sorun olmasına karşın bu sorunun irdelenmesi 1970’li yılların ortasında başlamıştır. Böylece oldukça hassas ve örtülü olan bu soruna karşı duyarlılık sağlanması ve önlenmesi adına yasal düzenlemelerin yapılması kadınların çalışma hayatında sayılarının artmasına ve Özellikle 1960'lı yıllarda harekete geçen kadın kuruluşlarının uğraşlarına dayalı olarak başlamıştır (Gerni, 2001: 20).

Cinsel tacizin, amir veya işveren tarafindan sergilenmesi durumunda yetkinin kötüye kullanımı söz konusudur ve güven ihlal edilecektir. Kişilik haklarının korunması, bireylerin uygun koşullarda çalışması, cinsiyet eşitliğinin sağlanması, durumun kişiler ve toplum açısından taşıdı̆̆1 önem göz önünde bulundurulduğunda, iş yerinde cinsel tacizi açıkça önleyen ve yasaklayan, kanıt yükünü kolaylaştıran, yaptırıma bağlayan, mağdurlara iş güvencesi sunan düzenlemelere gereksinin olduğu aşikardır (Bakırc1, 2006: 157-158).

4857 sayılı İş Kanunu'nda cinsel tacize dair herhangi bir tanım yapılmamakla birlikte Kanun, tacizin engellenmesi ve taciz mağduru işçinin korunması amacı ile cinsel tacize dair hem işçi hem de işveren açısından ayrıntılı düzenlemeler ve kurallar içermektedir.

Bu bağlamda cinsel taciz, 4857 say1lı İş Kanunu'nun 24. maddesinde işçinin haklı fesih nedenleri arasında sayılmıştır. Söz konusu maddenin II. Bendinin b fikrasi uyarınca "İ̧veren iş̧inin veya ailesi üyelerinden birinin şeref ve namusuna dokunacak sekilde sözler söjler, davranıslarda bulunursa veya isçiye cinsel tacizde bulunursa" ve d fikras1 uyarınca "İşinin diğer bir iş̧i veya üçüncü kişiler tarafindan isyerinde cinsel tacize uğramasi ve bu durumu işverene bildirmesine rağmen gerekli önlemler alınmazsa” bu durum işçi için hakli fesih sebebidir. Dahası kanunun 25. maddesinin II. bendinin c fikrasi uyarinca da "Isşinin işverenin başka bir iş̧isine cinsel tacizde bulunması" durumunda işveren, tacizci işçinin iş sözleşmesini haklı nedenle feshedebilecektir. İş Kanunu'nda iş sözleşmesinin haklı nedenle feshi durumlarından cinsel tacize dair düzenlemeleri içeren 24/II ve 25/II maddeleri "ablak ve iyi niyet kurallarna uymayan haller ve benzerleri” başlı̆̆1 altında ele alınmıştır.

Böylelikle İş Kanunu kapsamında iş yerinde cinsel taciz gerek işçi gerekse işveren açısından iş sözleşmesinin feshinde haklı neden oluşturmaktadır. Dolayısıyla söz konusu düzenlemeler ile cinsel taciz olayı yasal bir zemine oturtulmuş, işveren cinsel taciz durumunda mağdur işçiyi korumak ve önleyici tedbir almakla yükümlü kılınmıştır. Zira iş yerinde cinsel tacizi kişilik haklarına saldırı ve cinsiyet ayrımcılığı çerçevesinde değerlendirmek gerekmektedir. Nitekim işveren tacizde bulunan işçinin iş sözleşmesini haklı nedenle fesih edebileceği gibi, işçi de işveren tarafindan tacize uğramışsa iş sözleşmesini haklı nedenler feshetme hakkına sahiptir. Ayrıca başka bir işçi veya müşteri gibi üçüncü kişi tarafından 
cinsel taciz mağduru işçinin, işverene durumu bildirmesine karşın işveren mağdur işçinin kişilik haklarına yapılan saldırıdan dolayı işveren gereken önlemi almadı ise mağdur işçinin yine fesih hakkı bulunmaktadır. Burada işverenin alması gereken önlemler arasında tacizci veya mağdur işçinin çalışma yerini değiştirmesi, olayın tekrarını engellemek için çana sarf etmesi ve olayı kapatmaya çalışmaması, son raddede ise tacizin ağırlı̆̆ına göre tacizci işçinin işine son verilmesi olarak sıralanabilir. Ĕğer işveren bu önlemleri almış ise mağdur işçinin işverenin önlemleri almaması üzerinden fesih hakkı bulunmaz (Balkır, 2015: 27-28).

Netice itibariyle kanun kapsamında yalnızca işverenin tacizde bulunması durumundan değil başka bir işçinin veya üçüncü bir kişinin tacizde bulunması hallerine de yer verilmiştir. Taciz, işveren tarafindan gerçekleşti ise işçinin pek tabii haklı nedenle iş sözleşmesini feshedebilmektedir. Belirtildiği gibi tacizi gerçekleştiren başka bir işçi veya üçüncü bir kişi olması durumunda da işverenin sorumluluğu bulunmakta bu bağlamda gerekli önlemleri alması gerekmektedir. Şayet gereken önlemler işveren tarafindan alınmadı ise ancak bu durumda mağdur işçinin fesih hakk1 söz konusu olabilmektedir. Böylelikle Kanunun cinsel taciz durumunda mağdur işçiye fesih ve şikâyet hakkı tanığ1 görülmektedir. İşçinin bu haklı nedenle iş sözleșmesini feshedebildiği bu iki durumun yanı sıra Kanun işverene de cinsel tacizden dolayı haklı nedenle fesih imkânı tanımıştır. Sonuçta cinsel taciz hem işçi hem de işveren için haklı nedene dayalı derhal fesih nedeni olarak kabul edilmiştir.

Belirtmek gerekir ki cinsel tacizin, iş yerinde ya da dışında gerçekleşmesi ile mesai saatleri içinde ya da dışında gerçekleşmesi farksızdır. Zira bu fesih nedeninin temelinde, işverenin iş̧̧iyi koruma yükümüne aykırılık yatmaktadır. Bu noktadan hareketle koruma iş yeri ve iş ile sınırlı değildir. Örneğin, iş yerindeki bir işçinin eşinin hastalanması durumunda onun evine iğne yapmaya giden diğer bir işçinin eşe sarkıntılık etmesi, eşi sarkıntıllğa maruz kalan işçi için fesih nedeni sayılmıştır. Kaldı ki cinsel taciz ceza hukukunda suçtur (Akyiğit, 2020: 253).

Öte yandan cinsel tacize dair özellikle üzerinde durulması gereken bir nokta da cinsel tacizin ispatında yaşanılan zorluklardır. Zira cinsel taciz genellikle mağdur ile fail arasında bilinen bir eylem olarak kalabilmekte hatta mağdur çoğu zaman durumu dile getiremeyerek üstünü örtmekte, açıklasa bile inandırıcı ve ispatlayıc1 olmak konusunda güçlük çekebilmektedir. Bu konuda Yargıtay kararları oldukça önem arz etmekle birlikte Yargitay'n bir kararında ispat güçlügünün meydana getirdiği bu problemi mağdur lehine yorumlanarak çözümlendiği görülmektedir (Balkır, 2015: 31). Nitekim Yargitay 9. Hukuk Dairesi'nin 19.02.1998 karar tarihli ve 1998/2236 karar numaralı kararında; “...sarkintullk eylemleri cok zaman gizlli yapuldiğndan nitelikleri itibariyle görgü tanıklaryyla ispat mümkün olmayan olaylarder" şeklinde ifade edilmiştir (Günay, 2005: 765). Öte yandan Yargitay kararları incelendiğinde cinsel taciz olarak kabul edilen hareketler arasında genellikle mağdura söylenen cinsel içerikli sözlerin; telefon başta olmak üzere çeşitli iletişim yolları ile mağdurun sürekli rahatsız edilmesinin; müstehcen resim, mesaj 
gönderilmesinin, cinsel içerik ifade eden davranışlar sergilenmesinin yer aldığ görülmektedir (Çakıcı Gerçek, 2011: 78).

Bu bağlamda emsal gösterilebilecek bazı Yargitay kararları şu şekildedir:

"Samiğa iftira atmast için ciddi bir sebebi bulunmayan mağdurenin aşamalarda değģsmeyen beyanlar ve samiğa iliskin telefondan mağdurenin telefonunun birden faz̨la arandiğmm belirli olması ve gönderildiüi tespit edilen mesajin içeriği karşısında, sanğğn sarkintllhe (cinsel taciz) eylemi sabit olup, 5237 S. Kanun bükümlerinde değerlendirilmek suretiyle bir karar verilmesi gerektiği balde, yazll biçimde büküm kurulması," (5. Ceza Dairesi, Esas: 2004/789, Karar: 2005/22184, Tarih: 16.11.2005).

"Somut olayda, davacı taciz eylemlerinin basska işsilerden uzak yerlerde ve yalmiz iken gerceklesstiğini, ustabaşımn devaml bakışlarylla taciz ettiğini, kendisine yalmı kalmalarm sağlamaya yönelik işler verdiğini, etiketsiz dolaplara etiketlemek için o bölïme gittiklerini, etiket yanlarnda olmadiğindan almak için ayrolmak istediğinde ustanm șu an gerekli değil, ben gerekirse sana söylerim dediğini ve diğer olaylar samimi bir şekilde anlatmıs ve işverene de bildirmiştir. Gerekirse yü̈lesmeyi bile talep etmistir. Gerçekten, bir kadin işsinin namus ve iffetini etkileyebilecek sekilde nedensizyere kendisinin cinsel tacize uğradiğ yönünde bu kadar ayrnntılı olarak açılelamada bulunması hayatın olağan akışına aykırıdır. Davacınn samimi beyanlar ve dosyadaki bulgular doğrultusunda kıdem ve ibbar tazminatı taleplerinin kabulï gerekirken reddi hatalidrr.” (9. Hukuk Dairesi, Esas: 2008/14529, Karar: 2010/1463, Tarih: 28.01.2010).

"... is yerinde çalışan kadmn işşiye karşı cinsel tacizde bulunduğu açı olan davacomn iş akdinin feshinin haklh nedene dayandiğ anlaşıldğgndan, kıdem ve ibbar tazminatı taleplerinin reddi gerekirken mabkemece yerinde ve yasal olmayan gerekse ile kabulï batali olup, ..." gerekcesi ile verdiği bozma karar usul ve yasaya uygun olup, dosya kapsamma göre davacmon sabit olan taciz eyleminin psikolojik ve sosyolojik etkileri dikekate alindiğinda, karşıllğında fesih müeyyidesinin uygulanmasinm "cok ağır bir yaptomm" olarak nitelendirilmesinin kabul edileme ₹liği karşısında direnmenin yerinde olmadiğ anlaşıldiğzndan..." (9. Hukuk Dairesi, Esas: 2019/6572, Karar: 2019/16671, Tarih: 25.09.2019). (https://www.hukukturk.com/yargitay-kararlari).

Söz konusu düzenlemelerin iş yerinde cinsel tacizi önlemede yeterli olup olmadığı oldukça tartışmalıdır. İş yerinde cinsel tacizin engellenmesi öncelikli olarak iş yerinde sağlıklı bir iletişim ağının oluşturulması, hiyerarşinin her basamağında sorumluluğun benimsenmesi ve işçilere bu konuda eğitim verilmesine bağlıdır. Tabii ki iş yerinde cinsel tacizin, ayrımcllı̆ı̆n engellenmesi ve eşit bir ortam yaratılmasında temel sorumluluk işverene aittir. Ancak konuya yasal açıdan bakıldığında cinsel tacizin önlenmesine dair tedbirler alınması hususunda tüzük ve yönetmeliklerin çıkartılmasına ihtiyaç olduğu düşünülmektedir. İşverenler, cinsel taciz konusunda iç yönetmelikler hazırlamak ile yükümlü kılınabilir (Özdemir, 2006: 91-92). 


\section{Iş Kanunu Kapsamında Psikolojik Taciz}

Tacizi yalnızca cinsel taciz ile sinırlandırmak ve psikolojik tacizi göz ardı etmek oldukça sı̆̆ bir yaklaşım olacaktır. Zira iş yerlerinde psikolojik taciz oldukça kompleks bir sorun olarak karşımıza çıkmaktadır.

İş yerinde psikolojik taciz ya da küresel düzeydeki yaygın ismi ile mobbing, esasen çalısma hayatının var oluşu kadar eski bir olgudur. Mobbing, kültürel farklılıkları gözetmeksizin bütün iş yerlerinde varlık gösterebilen ve cinsiyet gözetmeksizin herkesin karşı karşıya kalabileceği, sonuçları oldukça ağır çok boyutlu ve karmaşık bir durumdur (Tinaz, 2006: 13).

Psikolojik taciz, işçinin manevi kişiliğine karşı yöneltilen, insanlık onuru ile bağdaşmayan, aşağılama, kötü muamele, dışlama gibi formlarda sergilenen kişiyi küçük düşüren ve yıldıran tekrarı olan davranışlardır (Süzek, 2017: 440). Yargıtay’a göre ise, işçilerin sistematik biçimde birbirine düşmanlık beslemesi, kasten zorluk çıkarması veya bu davranışların işveren ya da işveren vekillerince yapılması psikolojik tacizdir (Mollamahmutoğlu, Astarlı, Baysal, 2019: 186).

$\mathrm{Bu}$ bağlamda psikolojik taciz, bir çalışanın başka bir çalışan veya işveren tarafından kasıtlı biçimde sürekli ve sistematik olarak psikolojik saldırı yolu ile yıpratılmasıdır. Böylece mağdur çalışan ruhsal, fiziksel ve sosyal açıdan yıpranmakta ve bu durum iş verimliliğini etkilemekte hatta çalışanın işten ayrılmasına yol açabilmektedir. Örgüt düzeyinde ise, örgütün başarı ve verimliliğini olumsuz etkilemekte bu durum ülke ekonomisine de yansımaktadır (İlhan, 2010: 1175).

İş yerinde psikolojik taciz farklı davranış şekilleri ile kendini göstermektedir. Örnek vermek gerekirse işçiye sürekli bağırılması, devamlı eleştirilerek iş yaptırılması, işçinin bazı davet ve etkinliklere kasıtlı olarak çağırılmaması, dışlanması, aşırı iş yükü altına sokulması, yetki altına girmeyen işler verilmesi, fiziksel özellikleri ya da giyim tarzıla alay edilmesi, asılsız söylentiler çıarılması, hak ettiği yetkilerin verilmemesi gibi davranışlar psikolojik taciz olarak kabul edilebilir. Ancak belirtmek gerekir ki bu davranışların sistematik bir bicinde tekrarlanması söz konusu ise psikolojik taciz söz konusu olabilir. Diğer bir ifadeyle cinsel tacizde istenmeyen hareket anlık bir şekilde gerçekleşebildiği halde psikolojik taciz süreklilik arz eden hareketlerden meydana gelen bir süreçtir (Süzek, 2017: 440-441).

Yapılan tanımlamaların ortak noktası göz önüne alındığında, psikolojik tacizin, münferit eylemlerden meydana gelen bir durum değil, bir "süreç" olduğuna dikkat çekmekte fayda vardır (Ekmekçi ve Yiğit, 2020: 299).

Psikolojik taciz, çalışma yaşamının var oluşundan bu yana varlık göstermesine rağmen psikoloji ve hukuk literatürü açısından yeni ve önemli bir kavramdır. Mobbingi önemli kılan ise bu taciz türünün iş yerlerinde sıklıkla yaşanması ve hem mağdur bireyin hem de örgüt verimliliğinin üzerinde ağır tahribat yaratmasıdır. Öyle ki mobbing, iş yerlerinde cinsel ya da fiziksel tacizden daha sık yaşanan ve çalısanların manevi bütünlüklerini, şahıs varlıklarını negatif etkileyen bir olgudur. Ancak bu taciz türü diğerlerine göre tanısı daha zor konan 
hatta iş yerinde kimi zaman rekabet ortamında normal görülen ve görmezden gelinebilen bir saldırı biçimidir (Demircioğlu, 2007: 115).

İşverenin gözetme borcu, büyük oranda işçinin kişilik haklarının korunmasına yöneliktir. Bu anlamda işveren işçinin onurunu zedeleyici, iş yerinden dışlayıcı her türlü eyleme karşı işçiyi korumakla yükümlüdür. Dolayısıyla gözetme borcu gereğince işçinin kişiliğinin korunmasının bir yönünü oluşturan psikolojik taciz, bu konudaki önemi nedeniyle hukukumuzda yarg1 kararlarına konu olduğu gibi yasal düzenlemelerde de yer almaktadır (Mollamahmutoğlu, Astarlı, Baysal, 2019: 186).

Borçlar Kanunu'nun 417. maddesinin 1. fikrasında İş Kanunu kapsamında açık bir şekilde yer almayan psikolojik tacize (mobbing) de yer verilmiştir. Türkiye İnsan Hakları ve Eşitlik Kurumu Kanunu'nun 2. maddesinin $\mathrm{j}$ fikrasinda ise genel olarak taciz "Psikolojik ve cinsel türleri de dabil olmak. üzere bu Kanunda saynlan temellerden birisine dayanılarak, insan onurunun çignnenmesi amacm tasıyan veya böyle bir sonucu doğuran

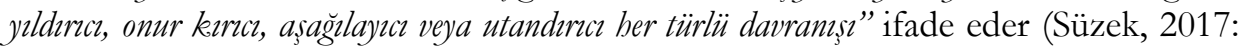
440). İş Kanunu açısından konu ele alındığında ise 8. maddede "İs sözleşmesi, bir tarafin (iş̧̧i) bağzmh olarak is görmeyi, diğer tarafin (ișveren) da ücret ödemeyi üstlenmesinden oluşan bir sözleşmedir" hükmü yer almaktadır. Söz konusu hükme göre "bağmmlllk" ile işçinin işverenin emir ve talimatlanına göre işi yerine getirmesi kastedilirken işçinin de bu bağımlılı̆̆ın karşıllı̆ında işçiyi koruma, gözetme ve eşit davranma borcunun olduğu ifade edilmektedir. Bu durum psikolojik taciz durumundaki tutumların, iş sözleşmesine aykırı eylemler olması ve gözetme borcu çerçevesinde işverenin işçinin bütün kişilik değerlerini koruma yükümlülüğünü göz ardı ettiğini göstermektedir. Dolayısıyla iş yerinde psikolojik tacizin ana ekseni, İş Kanunu kapsamında "baksız fiil ve borca aykurnllk yolu ile işşinin kişilik hak.k.mm iblal edilmesi" ile değerlendirilebilir. Ancak yine de taciz konusunda İş Kanunu'nda yalnızca cinsel tacizle ilgili düzenlemeler bulunmakta psikolojik tacize dair açık bir hüküm bulunmamaktadır (İhan, 2010: 1181).

Psikolojik taciz olarak değerlendirilebilecek eylemlerin İş Kanunu'nda fesih yaptırımına bağlandığ1 söylenebilir. Kanunun 24. maddesinin "ablakk ve iyi niyet kurallarna uymayan haller ve benz̧erleri" başlı̆ıını taşıyan II. Fıkrasının a, b ve c bentlerinde psikolojik taciz olarak nitelendirebileceğimiz davranışlar derhal fesih nedenleri arasında saylmıştır. Söz konusu düzenlemeler ise: "a) Iş̧veren iş sözleşmesi yapıldiğı sirada bu sözlessmenin esash noktalarndan biri bakkenda yanlis vasiflar veya sartlar göstermek yahut gerçeğe uygun olmayan bilgiler vermek veya sözler söylemek suretiyle işsciyi yamiltrsa. b) Ișveren işsinin veya ailesi üyelerinden birinin şeref ve namusuna dokunacak sekilde sözler söyler, davramışlarda bulunursa veya isçiye cinsel tacizde bulunursa. c) İsveren isçiye veya ailesi üyelerinden birine karşı sataşmada bulunur veya gözdağ verirse, yahut işşiyi veya ailesi üyelerinden birini kanuna karşı davranışa özendirir, kışkırtur, sürükler, yabut işsciye ve ailesi

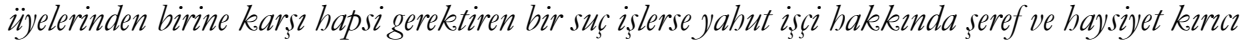
asılsı ağır isnad veya ithamlarda bulunursa." şeklinde kanunda yer almaktadır. Aynı şekilde, işçi tarafından işverene veya başka bir işçiye yapılan psikolojik tacizler de 
işverenin haklı nedenle derhal fesih hakkını benzer bir biçimde düzenleyen İş Kanunu madde 25 hükmü kapsamında değerlendirilebilir (Demircioğlu, 2007: 136).

Netice itibariyle psikolojik tacize yönelik İş Kanunu'nda doğrudan ve açık bir düzenleme bulunmamakla beraber psikolojik taciz olarak adlandirlabilecek eylemlere temas eden herhangi bir hükmün olmadığını ileri sürmek de yanlış olacaktır. Nitekim İş Kanunu psikolojik taciz çerçevesindeki davranış biçimlerine yeterli düzeyde ve doğrudan olmasa da koruyucu bir hukuki dayanak sağlamaktadır (İlhan, 2010: 1182). Öte yandan önemle belirtmek gerekir ki hem psikolojik tacize hem de cinsel tacize dair doğrudan pozitif düzenleme 6098 sayllı Türk Borçlar Kanunu'nda yer almaktadır. Bu kapsamda Türk Borçlar Kanunu ile ilk defa psikolojik taciz terimine yer verilmiştir. Türk Borçlar Kanunu'nun 417. maddesine göre; 'İ̧veren, hizmet ilişkisinde işşinin kişiliğini korumak ve saygu göstermek ve işyerinde dürüstliuk ilkelerine uygun bir düzeni sağlamakla, özellikle isçilerin psikolojile ve cinsel tacize uğramamalar ve bu tür tacizlere uğramıs olanlarn daha faz̧la zarar görmemeleri için gerekli önlemleri almakla yükümlüdür.” Bu bağlamda söz konusu düzenleme ile işçilerin psikolojik ve cinsel tacizden korunmaları hususunda işveren hizmet ilişkisi alanı içerisinde sorumlu kılınmışır. İşverenin gerek psikolojik gerekse de cinsel tacize karşı sorumlu kılınması, işçinin çalışma yaşamında karşılaşabileceği tehlikelere karşı işverence korunmasına yönelik bir düzenlemedir ki bu düzenleme ile birlikte işçinin psikolojik ve cinsel tacize karşı korunmasının kanunda açıkça zikredilmesinin özellikle kadın işçilerin çalışma yaşamı açısından oldukça önemli olduğu düşünülmektedir.

Tüm bunlarla birlikte psikolojik tacize maruz kaldığını iddia eden işçinin kural olarak bu iddiasını ispat etme yükümlülüğü bulunmaktadır. Bu kapsamda iş yerindeki yazışmalar, kamera kayıtları, tanıklar gibi deliller aracılı̆̆ı ile ispat mümkündür. Ancak psikolojik tacizin ispatı her zaman kolay olmamaktadır. Çünkü tanığın olmadığı alanlarda veya sadece sözlü biçimde yaşanabilmektedir. Bu durumu dikkate alan Yargitay, bu tür tacizin ispat edilmesi adına "kesin ispat" şartını aramamakta, "yaklaşı ispatı" yeterli bulmaktadır (Ekmekçi ve Yiğit, 2020: 300).

\section{Kadın Iş̧̧ilerin Kıdem Tazminatı Bakımından Hakları}

Kıdem tazminatı, Kanunda belirtilen fesih durumlarında Kanun gereği işverenin, en az bir yıllık kıdeme sahip işçiye veya işçinin ölümü durumunda hak sahiplerine verilmesi gereken, miktarı işçinin kıdemine ve son brüt kazancına göre tespit edilen bir ödemedir. Zira kıdem tazminatı işçilere Kanun ile tanınan bir haktır (Limon, 2015: 148).

4857 sayllı İş Kanunu'nun yürürlüğe girmesi ile birlikte 1475 sayılı İşs Kanunu'nun kıdem tazminatına dair 14. maddesi haricindeki diğer maddeleri mülga edilmiştir. $\mathrm{Bu}$ doğrultuda kıdem tazminatına yönelik yeni bir düzenleme getirilinceye dek 1475 saylı Kanun'un kıdem tazminatına dair hükümlerinin uygulanmasina aynen devam edilmektedir (Kurt, 2018: 80-81). 
1475 sayılı İş Kanunu'nun 14. maddesinde ise işçinin kıdem tazminatına hak kazanmasına imkân sunan fesih halleri ifade edilmiştir. Burada yer alan nedenler işçi tarafından iş sözleşmesini haklı nedenle feshedilmesini sağlayan durumlar değildir. Bu nedenler işçi tarafından haklı neden dışındaki bazı durumlarda, menfaat dengesinin gözetilmesi adına, işçiye iş sözleşmesinin feshedilmesi ve kıdem tazminatı hakkının sağlandığı hallerdir. Bu kapsamda askerlik, emeklilik, yaşlılık, evlilik, malullük ve toptan ödeme amacı ile işten ayrılan işçiler ele alınmıştır (Ocak, 2013: 575-576).

Çalışma konumuz kapsamında kadın işçinin kıdem tazminatı ise söz konusu kanunun 14. maddesinin (e) bendinde düzenlenmiştir. Buna göre "Kadmm evlendiğgi taribten itibaren bir ynl içerisinde kendi rızasi ile is sözleșesini sona erdirmesi durumunda" kıdem tazminatına hak kazanacağına hükmedilmiştir. Böylece kadın işçiler, evlendikten sonra bir yıl içerisinde iş sözleşmelerini feshetmeleri durumunda kıdem tazminatına hak kazanmaktadırlar. Belirtmek gerekir ki kadınların bu haktan faydalanmaları için ilk evliliklerinin olması zorunluluğu bulunmamaktadır (Kurt, 2018: 80-81). Hatta daha önce boşanmış olduğu eşi ile yeniden evlenen kadın işçinin de kıdem tazminatına hak kazanması söz konusu hüküm gereğince mümkündür. Dolayısıyla bu hükmü yeni evlenen kadın işçiye hasretmek yanlış olacaktır (Narmanlıoğlu, 2014: 578).

Nitekim konuya dair yer alan düzenleme ekseninde kadın işçinin kıdem tazminatına hak kazanabilmesi üç şarta bağlıdır. Birincisi, kadın çalışırken evlenmesi gerekmektedir. Dolayısıyla kadın işçi, sözleşmesini feshettikten ve işten ayrıldıktan bir gün sonra bile evlenmesi durumunda kıdem tazminatı hakkından yararlanması söz konusu değildir. İkincisi, iş sözleşmesini fesih eden taraf kadın işçi olmalıdır. Üçüncüsü, iş sözleşmesinin feshi evlilik tarihinden itibaren bir yll içerisinde yerine getirilmelidir (Limon, 2015: 157).

Evlenen kadına kıdem tazminatı hakkının tanınması ile evlilik nedeni ile istifa eden kadının korunması, maddi yoksunluğunun önüne geçilmesi fikrinden yola çıkılarak ileri bir adım olarak görülmüştür. Oysaki bu durum kadını çalışma hayatından koparmaya ve ev ile sinırlandırılmasına neden olabilmekte bu konuda teşvik edici olabilmekte ve kısa vadede maddi olarak korunuyor gibi görünen kadın, uzun vadede ekonomik özgürlügünü kaybedebilmektedir. Dolayısıyla çalışma hayatında kadının korunması adına hizmet verecek düzenlemelerin, kadını çalışma hayatından koparmaya teşvik edecek nitelik taşımasından ziyade eşinin iznine bağlı çalışan kadınların yer aldığı toplumsal zihniyeti değiştirmeye yönelik olmalıdır (Centel, 2009: 6).

Nihai olarak kadın çalışana tanınan bu olanak her ne kadar kadınlara pozitif ayrımcılık sağlanması amacına yönelik olsa da bu olanak, kadınların çalışma yaşamından daha kolay çekilmelerine de yol açabilmektedir. Dahası bu uygulama, suistimallere açık bir meseledir (Limon, 2015: 157).

Zira Yargıtay, bu konuya dair meydana gelen bir uyuşmazlıkta kadın işçinin kıdem tazminatı talebini reddetmiştir. Şöyle ki, Yargıtay 9. Hukuk Dairesi’nin, 
18.09.1989 tarihli, 6776-6979 kararına göre, evlilik sırasında şiddetli geçimsizlik sebebiyle boşanan ancak çok kısa bir süre zarfında eski eşi ile yeniden evlenen daha sonra ise iş sözleşmesini feshederek kıdem tazminatı talep eden kadın işçinin bu tutumu kanuna karşı hile olarak addedilmiş ve isteği kabul edilmemiştir. Öte yandan, Yargitay 9. Hukuk Dairesi'nin 2001/16313 E. 2001/1306 K. say1l ilamında; "Kadin isscinin evlilik nedeniyle ayrlmasindan sonra tekrar başka bir işe girmesi onun kötü niyetli olduğu anlamına gelmez. Zira böyle bir durumda Anayasal çalıs̆ma bakekmm ön planda geldiği kabul edilmelidir. Bundan baskea aile hayat gerekleri de har zaman göz. önünde tutulmalıdır." ifadesiyle kadın işçinin tekrar çalışmaya başlamasında hukuksal bir engel olmadığı vurgulanmıştır. Böylece Yargıtay kararına göre evlilik nedeni ile işten ayrılarak kıdem tazminatını elde eden kadın işçinin gelir ihtiyacı nedeni ile yeniden başka bir işe girmesi durumunda kanuna karşı bir hileden ya da hakkın kötüye kullanılmasından bahsedilemeyecektir. Ayrıca belirtilmesi gereken bir nokta da kadınlar için bu düzenlemenin Anayasa'nın 10. maddesi kapsamında yer alan eşitlik ilkesine aykırı olduğu ileri sürülmesi ancak bu itirazın Anayasa Mahkemesi'nin oy çokluğu ile reddetmesidir (Taşkent ve Kurt, 2014: 46-47). Böylelikle kadın işçinin evlilik sebebiyle sözleşmeyi feshetme durumunda aldığ1 kıdem tazminatı, işten ayrılan kadının daha sonra çalıșmaya başlamasına engel teşkil etmemektedir (Narmanlıŏlu, 2014: 580).

Nitekim Yarg1tay kararına göre; "... Kadın iş̧̧inin evlilik sebebine bağh feshinin ardından kısa bir süre sonra yeniden çalıșmasımin gerekleri ortaya çımıs olabilir. Hatta kadın isçi evlilik sebebine dayah feshin ardindan ara vermeksizin başka bir isyerinde çalısmaya başlayabilir ve bu durum evliliğin kadina yüklediği görevlerin yerine getirilmesi noktasinda daba olumlu sonuclar doğurabilir." (22. Hukuk Dairesi, Esas: 2015 /23042, Karar: 2015/27860, Tarih: 8.10.2015). (https://www.hukukturk.com/yargitay-kararlari).

Dolayısıyla kadın işçinin evlenme sebebiyle sözleşmeyi feshedip kıdem tazminatı aldıktan sonra isterse ertesi gün başka bir işveren yanında çalışmaya başlaması feshin kötü niyetli veya haksız olduğunu göstermez. Yarg1tay'ın söz konusu kararlarından anlaşılacağ1 üzere de Yargıtay kararları da uzun süredir bu eğilimdedir. Ancak konuya dair Yargitay'ın yakın tarihli farklı kararı da mevcuttur. 9. Hukuk Dairesi'nin, 17.02.2020 tarihli, 14500/2329 kararına göre, "işşinin yaptrğ usulsüqlükler üzerine isverence sorusturma açlip savunmasinı alinmasi üzerine evlenerek sözlesmeyi evlenme nedeniyle feshedip kudem tarminat istemesi halinde isçinin yaptı̆̆ bu fesibte fesih hakekın kötüye kullandı̆̆ sonucuna varılmıstır." (Akyiğit, 2020: 349).

\section{Sonuç}

Kadınlar tarih boyunca farklı şekillerde üretim faaliyetlerine katılsalar da ücret karşılığı çalışmaları Sanayi Devrimi ile birlikte gerçekleşmiştir. Kadınların çalışma hayatında varlık göstermeleri tüm dünyada oldukça uzun bir süreci gerektirmiştir. $\mathrm{Bu}$ durumun temelinde kadın ve erkeğe atfedilen toplumsal cinsiyet rollerinin olduğunu söylemek mümkündür. Zira bu roller kadınları ev içi işler ile sorumlu 
kılmış nihayetinde kadın özel alanla özdeşleşmiştir. Kamusal alana hâkim olan ve evi geçindirmekle sorumlu tutulan erkek ise çalışma hayatının baş aktörü olarak yüzylllarca rol oynamış kadınlar ise ikincil konumda kalmıştır.

Tüm bunlara bağlı olarak kadınlar gerek işe giriş aşamasında gerekse iş hayatlarında çeşitli sorunlarla karşı karşıya kalmaktadırlar. Bu sorunları işe giriş̧ aşamasında engel teşkil eden eğitimde eşitsizlik, gelenekselleşmiş sosyo-kültürel engeller, işe alımlarda cinsiyete dayalı ayrımcllık ve işe girdikten sonrasında iş bölümünde, yükselmelerde ve ücretlendirmede cinsiyete dayalı ayrımcılık, kadınların hamilelik ve annelik niteliklerinin işverence maliyetli görülmesi, kadınların ev içi sorumlulukları nedeni ile yaşadıkları iş-aile çatışması, sosyal güvenlik sorununa sahip enformel çalışma şekilleri, psikolojik ve cinsel taciz şeklinde sıralamak mümkündür. Bu bağlamda çeşitli ve çok yönlü sorunlara sahip olan kadınların yasal düzenlemeler ile korunması gerekmektedir. Nitekim İş Kanunu göz önüne alındığında eşit davranma ilkesinin ve ayrımcılık yasağının bulunduğu görülmektedir. Bu kapsamda Kanunda sırf cinsiyetten ötürü ayrım yapılamayacağ1 açıkça belirtilmiştir. Ancak ne yazık ki uygulamada farklı tutumlar gerçekleşebilmektedir. Ayrıca Kanun kapsamında kadınların yer ve su altında çalıştırılmasına ve gece çalıştırılmasına dair düzenleme ile hem kadınların fiziksel nitelikleri göz önünde bulundurulmuş hem de ailedeki sorumlulukları ve aile düzeninin korunması amaçlanmıştır. Kanun kapsamında kadın işçileri korumaya yönelik diğer bir düzenleme ise hamilelik ve analık halinde kadınlara tanınan bazı haklardır. Bu noktada Kanun kadınların çalışma hayatına katılırken yalnızca çalışan kimliğine değil aynı zamanda eş, anne ve ev hanımı kimliklerine de sahip olduğunu ve doğurganlık özellikleri nedeni ile kadınlara özgü gereksinimleri göz önünde bulundurmuştur. Zira bu kimlikler kadının bir nevi çifte mesai yapması anlamına gelmektedir. $\mathrm{Bu}$ nedenle iş yerlerinde çocuk bakımı konusunda kadınların yükünü hafifletecek nitelik ve nicelikte kreşlerin ve yaşlı bakımını üstlenecek kamusal hizmet kurumlarının tertip edilmesi kadınların çalışma hayatına katılımları açısından oldukça gereklidir. Bu noktada yasal düzenlemeler olmakla birlikte gelişimine ihtiyaç olduğu söylenebilir. Kanun kapsamında kadınları tacize karşı koruyan düzenlemeler değerlendirildiğinde ise cinsel tacize dair açıkça öngörülen hükümlerin yer aldığ1 ancak psikolojik tacizin doğrudan ve açıça düzenlenmemesine karşın psikolojik taciz olarak adlandırılabilecek davranışlar hakkında yasal bir dayanak olduğunu söylemek mümkündür. Bu bağlamda taciz konusunun normalleştirilememesi adına söz konusu sorunun daha detaylı ele alınması ve daha caydırıcı yaptırımlar öngörülmesine ihtiyaç vardır. Kadınları korumaya yönelik öngörülen diğer bir hak ise kıdem tazminatıdır. Ancak kıdem tazminatı her ne kadar kadınların evlenmeleri durumunda mağdur olmamaları adına onlara tanınan bir imkân gibi düşünülse de bu durum geleneksel toplumsal bakış açısı ile birleştiğinde kadınların çalışma hayatı açısından caydırıcı nitelikte de olabilmektedir. 
Tüm bu düzenlemelerden yola çıkılarak kadınların çalışma hayatında karşılaştıkları birçok sorunun İş Kanunu kapsamında ele alındığı görülmektedir. Ancak bu düzenlemelerin uygulamaya aktarılması hususunda eksiklikler yaşandığ1 ve bazı düzenlemelerin caydırıcı nitelikte de algilanması sebebiyle yaptırım ve denetleme konusunda yasal mevzuatın gözden geçirilmesi gerektiği söylenebilir. Öte yandan yaşanan tüm bu sorunların önüne geçilmesi ve alınan yasal tedbirlerin anlam kazanabilmesi adına sorunun kökenine inilerek toplumsal düzeyde derin dönüşümlerin gerçekleşmesi gerektiği düşünülmektedir.

Nitekim yasal düzenlemelerin yanı sıra uygulamada kadınların işgücü piyasasına katılımlarını arttırmak ve hakları konusunda farkındalık yaratmak adına kamu kuruluşlarına, yerel yönetimlere, yükseköğretime, özel kesime, sivil toplum kuruluşlarına ve medyaya önemli görevler düşmektedir. Dahası kadınların çalışma hayatına katılımları ve çalışma hayatı içerisinde de haklarının korunması adına öncelikle geleneksel bakış açısının ve toplumsal bakış açısının değişmesi gerekmektedir. Ancak bu şekilde kadınlar erkeklere sunulan temel firsatlara sahip olarak ucuz iş gücü veya ikincil statüsünden kurtulur. Bilhassa temelde eğitim imkânlarına daha yeterli seviyede ulaşabilen kadınlar, erkekler ile eşit koşullarda rekabet edebilmenin ve hem iktisadi hem de sosyal hayatta varlik gösterebilmelerinin ilk adımını atmış olacaklardır. Nitekim kadınların eğitim seviyesi ile çalışma hayatında varlık gösterebilmeleri paralel bir seyir izleyecek hatta bu durum siyasi temsil ve katılımlarına da pozitif olarak yansıyacaktır. Böylelikle çalışma hayatında kadınları dezavantajlı duruma düşmelerinin önündeki engellerin ortadan kaldırılması ile kadınlar kamusal alanda da hak ettikleri değere kavuşabilecek, görünürlüğü artacak ve söz sahibi olabileceklerdir. Öte yandan nüfusun neredeyse yarısını oluşturması açısından kadın istihdamının hem toplumsal yapıyı güçlendirmeye hem de sürdürülebilir ekonomik kalkınmaya etkisi göz ardı edilemeyecek bir husustur. Bu nedenle İş Kanunu başta olmak üzere mevzuatta çalışan kadınları korumaya yönelik düzenlemeler oldukça önemli bir role sahiptir. Neticede yasal mevzuatın uygulamaya aktarılmasındaki sorunların giderilmesi ve yönetişim içerisinde işbirliği ile her bir bireyin ve kuruluşun üstüne düşen görevi yerine getirmesi gerekli görülmektedir. Bu doğrultuda konuya dair çalışmalar çeşitlendirilerek artırılmalıdır. 


\section{KAYNAKÇA}

Aksöz, F. ve Eroğlu Durkal, M. (2021) “Çalışma Hayatında Kadınların Karşılaştıkları Sorunlar: Kayseri İlinde Çalışan Kadın Öğretmenler Üzerine Bir Araşturma”, Erciyes Üniversitesi İktisadi ve İdari Bilimler Fakültesi Dergisi, (59), 141-176.

Akyiğit, E. (2020) Bireysel İş Hukuku Ders Kitabı, Ankara: Seçkin Hukuk.

Alparslan, A. M., Çetinkaya Bozkurt, Ö. ve Özgöz, A. (2015) "İşletmelerde Cinsiyet Ayrımcılı̆̆ı ve Kadın Çalışanların Sorunları", MAKÜ İktisadi ve İdari Bilimler Fakültesi Dergisi, 2(3), 66-81.

Arslan Ertürk, A. (2017) "Kadın İşçilerin Çalışma Şartlarına İlişkin Türk İş Mevzuatının Öngördüğü Düzenlemelere Genel Bir Bakış”, Marmara Üniversitesi Hukuk Fakültesi Hukuk Araştırmaları Dergisi, 23(1), 345369.

Bakırcı, K. (2006) "Türk İş Hukukunda Kadın İşçilerin İnsan Hakları", Ankara Barosu Hukuk Kurultayı, 03-07 Ocak, Ankara.

Balkır, Z. G. (2015) “Cinsiyet Ayrumcılığı Temelinde İş Yerinde Cinsel Taciz", İstanbul Aydın Üniversitesi Hukuk Fakültesi Dergisi, 1(1), 1-36.

Bingöl, O. (2014) “Toplumsal Cinsiyet Olgusu ve Türkiye'de Kadınlık”, KMÜ Sosyal ve Ekonomik Araştırmalar Dergisi, 16(Özel Sayı I), 108-114.

Centel, T. (2009) “Kıdem Tazminatında Pozitif Ayrımcılık”, Sicil İş Hukuku Dergisi, $15,5-10$.

Çakıc1 Gerçek, L. (2011) "Yarg1tay Kararlarıyla Cinsel Taciz Suçu”, Ankara Üniversitesi Hukuk Fakültesi Dergisi, 60, 47-82.

Çakır, Ö. (2008) "Türkiye'de Kadının Çalışma Yaşamından Dışlanması”, Erciyes Üniversitesi İktisadi ve İdari Bilimler Fakültesi Dergisi, 25-47.

Çelik, N., Caniklioğlu, N., ve Canbolat, T. (2020) İş Hukuku Dersleri, İstanbul: Beta Basim.

Dedeoğlu, S. (2009) 'Eşitlik mi ayrımcılık mı? Türkiye'de sosyal devlet, cinsiyet eşitliği politikaları ve kadın istihdamı", Çalışma ve Toplum, 2, 41-54.

Dedeoğlu, S. (2011) “Türkiye'de Cinsiyet Eşitliği Politikaları ve Kadın İstihdamı”, Kadın Emeği Konferansı TEPAV-ODTÜ Kadın Çalışmaları, Ankara.

Demir, Ş. (2009) "Mobbing Olgusunun Hukuki Değerlendirmesi”, Ankara Barosu Dergisi, 67(2), 139-145.

Demircioğlu, A. M. ve Centel, T. (2016) İş Hukuku, İstanbul: Beta Yayım.

Demircioğlu, H. R. (2007) “Kişilik Hakkı İhlâlinin ve Borca Aykırıllı̆ın Bir Türü Olarak İsyerinde Psikolojik Taciz (MOBBING)", Gazi Üniversitesi Hukuk Fakültesi Dergisi, 11(1-2) 113-145.

Derdiyok, B. (2014) "Yerel Seçimlerde Kadın Adayların Görünmezliği Sorunu", TÜRKSAM Uluslararası İlişkiler ve Stratejik Analizler Merkezi. 
Ekmekçi, Ö. ve Yiğit, E. (2020) Bireysel İş Hukuku Dersleri, İstanbul: On İki Levha Yayincilik.

Emziren Kadınların Çalıştırılma Şartlarıyla Emzirme Odaları ve Çocuk Bakım Yurtlarına Dair Yönetmelik. (2013, 16 Ağustos). Resmi Gazete (Say1: 28737).

Erişim adresi: https://www.resmigazete.gov.tr/eskiler/2013/08/201308168.htm

Gerni, M. (2001) "İşyerinde Cinsel Taciz: Erzurum İlinde Bankacılık Sektörü Üzerine Bir Uygulama", Ankara Üniversitesi SBF Dergisi, 56(3), 19-46.

Gözler, K. ve Kaplan, G. (2016) İdare Hukuku Dersleri, Bursa: Ekin Basın.

Gül, H., Yalçınoğlu, N. ve Atlı, Z. C. (2014) “Türkiye’de çalışma yaşamında kadının konumu ve sorunları", TAF Preventive Medicine Bulletin, 13(2), 169-176.

Hukukturk.com (2021). https://www.hukukturk.com/yargitay-kararlari (09.12.2021). Işık, V. (2013) "Kurumsal Sosyal Sorumluluğun Değiştirdiği Çalışma Kavramı ve Yeni Bir Çalışma Alanı Olarak Sosyal Girişimler”, Sosyal Güvenlik Dergisi (Journal Of Social Security), 3(1), 101-131.

İleri, Ü. (2016) "Sosyal Politikalarda Kadın ve Cinsiyet Ayrımcılığı İle İlgili Başlıca Uluslararası ve Ulusal Hukuki Düzenlemeler", HAK-İŞ Uluslararası Emek ve Toplum Dergisi, 5(12), 128-153.

İlhan, Ü. (2010) "İşyerinde Psikolojik Tacizin (Mobbing) Tarihsel Arka Planı ve Türk Hukuk Sisteminde Yeri”, Ege Akademik Bakış, 10(4), 1175-1186.

İş Kanunu. (2003, 10 Haziran). Resmi Gazete (Sayı: 25134). Erişim adresi:

https://www.mevzuat.gov.tr/MevzuatMetin/1.5.4857.pdf

Kadın Çalışanların Gece Postalarında Çalıştırılma Koşulları Hakkında Yönetmelik. (2013, 24 Temmuz). Resmi Gazete (Say1: 28717). Erişim adresi:

https://www.resmigazete.gov.tr/eskiler/2013/07/20130724-25.htm

Karabıyık, İ. (2012) "Türkiye'de Çalışma Hayatında Kadın İstihdamı", Marmara Üniversitesi İIBF Dergisi, 32(1), 231-260.

Kocacık, F. ve Gökkaya, V. B. (2005) “Türkiye'de Çalısan Kadınlar ve Sorunları”, C.

Ü. İktisadi ve İdari Bilimler Fakültesi Dergisi, 6(1), 195-219.

Korkmaz, A ve Korkut, G. (2012) "Türkiye'de Kadının İşgücüne Katılımının Belirleyicileri”, Süleyman Demirel Üniversitesi İktisadi ve İdari Bilimler Dergisi, 8(2), 41-65.

Korkmaz, M., Alacahan, N. D., Cesim, D. T., Yücel, A. S. ve Aras, G. (2013) "Türkiye'de Kadın İstihdamının Amerika Birleşik Devletlerindeki Kadın İstihdamı ile Karşılaştırılması", Turkish Studied Dergisi, 1846-1862.

Kurt, R. (2018) "Türk İş Hukukunda Kadın Çalışanların Hakları", Mali Çözüm Dergisi, 28, 59-90.

Limon, R. (2015) "Türkiye'de Kıdem Tazminatının Tarihi Gelişimi ve Kıdem Tazminat Fonu", İş ve Hayat, 147-170.

Mimaroğlu, H. ve Özgen, H. (2008) “Örgütlerde Güç Eşitsizlikleri ve Cinsel Taciz", Ç.Ü. Sosyal Bilimler Enstitüsü Dergisi, 17(1), 321-334. 
Mollamahmutoğlu, H., Astarlı, M., ve Baysal, U. (2019) İş Hukuku Ders Kitabı, Ankara: Lykeion Yayınları.

Narmanlıoğlu, Ü. (2014) İş Hukuku Ferdi İş İlişkileri I, İstanbul: Beta Basım.

Ocak, S. (2013) "İş Sözleşmesinin İşçi Tarafından Evlilik, Askerlik ve Sosyal Güvenlik Hakları Nedeniyle Feshinde İhbar Tazminatı", Dokuz Eylül Üniversitesi Hukuk Fakültesi Dergisi, 15(Özel Say1), 573-608.

Oğuz, Ö. (2018) “Türk İş Hukukunda Kadın Çalışanları Koruyucu Düzenlemeler”, TBB Dergisi, 134, 567-586.

Ören, D. ve Yüksel, H. (2012) “Geçmişten Günümüze Çalışma Hayatı”, Hak İş Uluslararası Emek ve Toplum Dergisi, 1(1), 35-59.

Özbudun, E. (2005) Türk Anayasa Hukuku, Ankara: Yetkin Yayınları.

Özdemir, E. (2006) "İşyerinde Cinsel Taciz”, Çalışma ve Toplum Ekonomi ve Hukuk Dergisi, 4(11), 83-96.

Parlaktuna, I. (2010) “Türkiye'de Cinsiyete Dayalı Mesleki Ayrımcılığın Analizi”, Ege Akademik Bakış, 10(4), 1217-1230.

Pekel, E. (2019) "Toplumsal Cinsiyet Rolleri ve Kadının Çalışma Yaşamındaki Konumu”, Balkan ve Yakın Doğu Sosyal Bilimler Dergisi, 5(1), 30-39.

Süzek, S. (2017) İş Hukuku, İstanbul: Beta Basım.

Taşkent, S. ve Kurt, D. (2014) “Uluslararası Düzenlemeler Çerçevesinde Türk İş Mevzuatında Kadın İşçinin Korunması”, Çalışma ve Toplum, 1(40), 29-50.

Tinaz, P. (2006) İşyerinde psikolojik taciz, İstanbul: Beta yayıncılık.

Türk Borçlar Kanunu. (2011, 4 Şubat). Resmi Gazete (Sayı: 27836). Erişim adresi:

https://www.mevzuat.gov.tr/MevzuatMetin/1.5.6098.pdf

Türkiye Cumhuriyeti Anayasası. (1982, 9 Kasım). Resmi Gazete (Say1: 17863 (Mükerrer)).

Türkiye İstatistik Kurumu (05 Mart 2021). Haber Bülteni (Say1: 37221). Istatistiklerde Kadın, 2020. Erişim adresi:

file: // /C:/Users $/ \% \mathrm{C} 4 \% \mathrm{~B} 0 \% \mathrm{C} 4 \% \mathrm{~B} 0 \mathrm{BF} /$ Downloads $/ \% \mathrm{C} 4 \% \mathrm{~B} 0$ statistiklerle_ $\mathrm{Kad} \% \mathrm{C} 4 \% \mathrm{~B} 1 \mathrm{n}$ 05.03.2021.pdf.

Y.9HD, 19.2.1998. E.1997/21644 - K.1998/2236, Günay, C. İ. (2005) İş Kanunu Şerhi, Ankara: Yetkin Yayınları.

Yılmaz, O. (2018) “Türk İş Hukukunda Postalar Halinde Çalışma”, Necmettin Erbakan Üniversitesi Hukuk Fakültesi Dergisi, 1(1), 83-110.

Yuvalı E. (2013) “4857 sayılı İş Kanunu’nun ve İlgili Mevzuatın Kadın İşçiler ile İlgili Hükümlerine Genel Bir Bakış”, TBB Dergisi, 106, 93-113. 
